2016

\title{
Planning for Density in a Driverless World
}

Sarah J. Fox

Georgetown University Law Center, sarah.fox@law.georgetown.edu

This paper can be downloaded free of charge from:

http://scholarship.law.georgetown.edu/ipr_papers/1 


\section{Introduction}

When we talk about sprawl, ${ }^{1}$ we talk about cars. Critiques of the low-density, highly consumptive development pattern frequently focus on time lost in traffic congestion and air quality degradation from exhaust emissions. ${ }^{2}$ Cars made sprawl in its current form possible, and suburban development has ensured the continued dominance of the automobile through design centered nearly entirely around its needs. That design has taken a toll on both humans and the environment. As development draws farther away from the city center, "commuters and commerce face barely tolerable and ever-worsening congestion on the highways." 3 In the United States, the time attributed to waiting in traffic in 2014 was 42 hours per person, a loss valued at $\$ 160$ billion nationwide. ${ }^{4}$ Automobiles are also responsible for approximately half of all carbon monoxide emissions and a sizable percentage of emissions of nitrogen oxides, volatile organic compounds, and particulate matter. ${ }^{5}$ Motivated in part by these adverse impacts, the past several decades have seen population growth and economic revitalization in urban centers across the United States.

\footnotetext{
${ }^{1}$ In very general terms, sprawl development is characterized by isolated centers of development, dedicated to single uses and accessible only by car, with residential developments segregated in clusters of units of similar cost. This kind of sprawl development "is limited only by the range of the automobile," and "[v]ehicular traffic controls the scale and form of space, with streets being wide and dedicated primarily to the automobile," and "[p]arking lots typically dominat[ing] the public space." See Andrés Duany \& Elizabeth Plater-Zybeck, "The Traditional Neighborhood and Urban Sprawl," in NEW URBANISM AND BEYOND: Designing Cities FOR THE Future 64, Tigran Haas, ed., Rizzoli: New York (2008). 2 See, e.g., Lewyn, Michael, Sprawl in Canada and the United States, 44 URB. LAW. 85, 86-87 (2012) (discussing sprawl in terms of "increased traffic congestion, air pollution, and greenhouse gas emissions"); Brawer, Judi \& Vespa, Matthew, Thinking Globally, Acting Locally: The Role of Local Government in Minimizing Greenhouse Gas Emissions from New Development, 44 IDAHO L. REV. 589, 598 (2008) (discussing “sprawl problems" as including traffic congestion and poor air quality); Span, Henry A., How the Courts Should Fight Exclusionary Zoning, 32 SETON HALL L. REV. 17, 17 (2003) (positing that "the increased commutes created by suburban sprawl cause greater traffic congestion and worse air quality"); Pollard III, Oliver A., Smart Growth and Sustainable Transportation: Can We Get There from Here?, 29 FORDHAM URB. L.J. 1529, 1554 (2002) (noting that the Atlanta region has "come to epitomize suburban sprawl, experiencing explosive, scattered development, heavy automobile dependence, skyrocketing traffic congestion, and poor air quality.”).

${ }^{3}$ Kushner, James A., The Post-Automobile City: Legal MeChanisms to Establish the Pedestrian-Friendly CITY 7 (Carolina Academic Press 2004); cf. Sultama, Selima and Joe Walker, "Journey-to-Work Patterns in the Age of Sprawl: Evidence from Two Midsize Southern Metropolitan Areas,” 59:2 THE Professional GEOGRAPHER 193, 199 (2007) ("The comparison of sprawling and urban areas confirms the prevailing view about sprawl, as average miles, commute time, and drive time are significantly longer for people living in sprawling areas compared to those living in denser urban areas ....”).

42015 Urban Mobility Scorecard, Texas A\&M Transportation Institute 1 (August 2015), available at http://d2dtl5nnlpfrOr.cloudfront.net/tti.tamu.edu/documents/mobility-scorecard-2015.pdf (last visited Aug. 27, 2015).

${ }^{5}$ Kushner, James A., Healthy Cities: The Intersection of Urban Planning, Law, And Health 98 (Carolina Academic Press 2007).
} 
Enter the driverless car. ${ }^{6}$ Better yet, the electric, driverless car. Changing automobile technology appears poised to produce a car in the near future that is fully electric and fully autonomous; elements of each are already on the road. ${ }^{7}$ These advances are likely to bring about better safety and air quality, and offer increased independence to large segments of the population. They are also likely to increase tolerance for time spent in transit. Congestion, gas prices, and the frustrations that come with time spent commuting have long served as an informal cap on sprawl. With those limitations lifted, development of ever greater swaths of land is foreseeable. Decades of suburban growth have shown that large scale low-density development has enormous negative consequences for the environment. ${ }^{8}$ A second major expansion in automobile traffic could therefore be devastating to biological diversity and ecosystem health across the United States. Density matters, even in a world of zero emissions and zero productive time lost to driving, because it is the means by which we control the human footprint on the larger ecosystem.

Although the potential impacts of the driverless car for density have been recognized in passing, those impacts have not played a prominent role in the growing conversation around this new technology. Instead, legal scholarship on autonomous vehicle technology has to date focused

\footnotetext{
${ }^{6}$ This Article uses the terms "driverless cars," "self-driving cars," "autonomous vehicles," and "automated vehicles" interchangeably.

7 See, e.g., Bill Vlasic, “Tesla’s New Model 3 Jump-Starts Demand for Electric Cars,” Business Day, THE NEW YORK Times (April 1, 2016), available at http:/ /www.nytimes.com/2016/04/02/business/teslas-new-model-3-jump-startsdemand-for-electric-cars.html? rref $=$ collection $\% 2$ Ftimestopic $\% 2$ FElectric $\% 20$ and $\% 20 H y b r i d \% 20$ Vehicles $($ describing advances in electric car market); see also, e.g., Rachel Abrams, "Self-Driving Cars May Get Here Before We're Ready," DealBook: Davos 2016 Special Report, THE NEW YORK TIMES (Jan. 21, 2016), available at http://www.nytimes.com/2016/01/22/business/dealbook/davos-self-driving-cars-may-get-here-before-wereready.html (noting the current availability of autonomous components in many vehicles, and describing the expected advances in technology).

8 See William A. Shutkin, The LAND THAT COUld BE: ENVIRONMENTALISM AND DEMOCRACY IN THE TwENTY-FIRST CENTURY 50, Cambridge: MIT Press (2000) (detailing the environmental impacts of suburbanization, including air pollution and destruction of habitat); see also, e.g., Sarah Fox, "CERCLA, Institutional Controls, and the Legacy of Urban Industrial Use, 42 Envtl. L., 1211, 1218 (2012) (describing commonly accepted environmental toll of sprawl development).
} 
primarily on questions of legality, ${ }^{9}$ or issues of liability, privacy, and public safety that will inevitably arise once autonomous vehicles are more broadly adopted. ${ }^{10}$ This Article takes a deeper look at the potential implications of this new technology for land use and the environment, and emphasizes the importance of planning for density independent of transportation technology. It also proposes possible responses to the driverless car at both the suburban and urban level. The informationforcing provisions of environmental review statutes, combined with practical ways in which policymakers can plan for the driverless car, may help to prevent another generation of scattered development centered on the needs of the automobile.

Planning for the future is a central component of ensuring the health of human communities and the broader ecosystem. ${ }^{11}$ As we look ahead to a driverless world, the benefits promised by autonomous vehicles for safety, air quality, and accessibility should not mean an unequivocal embrace of new technology. Nor should environmental concerns about development prevent the approval or progress of automated vehicles. Instead, the American planning dynamic should shift to

\footnotetext{
9 See generally Bryant Walker Smith, "Automated Vehicles are Probably Legal in the United States," 1 TEX. A\&M L. REV. 411 (2014) (positing that, because automated vehicles are not expressly prohibited, they are legal without further action by federal or state governments).

10 See, e.g., Sarah Aue Palodichuk, "Driving Into the Digital Age: How SDVs Will Change the Law and Its Enforcement," 16 Minn. J.L. SCI. \& TECH. 827 (2015); Robert Sykora, "The Future of Autonomous Vehicle Technology as a Public Safety Tool," 16 Minn. J.L. SCI. \& TECH. 811 (2015); Katherine L. Hanna, “Old Laws, New Tricks: Drunk Driving and Autonomous Vehicles," 55 JuRIMETRICs 2 (2015); Orly Ravid, “Don’t Sue Me, I Was Just Lawfully Texting \& Drunk When My Autonomous Car Crashed Into You,” 44 Sw. L. REV. 175 (2014); Sophia H. Duffy \& Jamie Patrick Hopkins, "Sit, Stay, Drive: The Future of Autonomous Car Liability," 16 SMU SCI. \& TECH. L. REV. 453 (2013); Alexander Herd, "R2DFord: Autonomous Vehicles and the Legal Implications of Varying Liability Structures," 5 FAULKNER L. REV. 29 (2013); Jeffry K. Gurney, "Sue My Car Not Me: Products Liability and Accidents Involving Autonomous Vehicles," 2013 U. ILL. J. L. TECH \& POL’Y 247 (2013); Rachael Roseman, “When Autonomous Vehicles Take Over the Road: Rethinking the Expansion of the Fourth Amendment in a Technology-Driven World," 20 RICH. J. L. \& TECH. 1 (2013); Frank Douma and Sarah Aue Palodichuk, "Criminal Liability Issues Created by Autonomous Vehicles," 52 SANTA Clara L. ReV. 1157 (2012); Gary E. Marchant and Rachel A. Lindor, "The Coming Collision Between Autonomous Vehicles and the Liability System," 52 SANTA Clara L. REV. 1321 (2012); Kyle Graham, "Of Frightened Horses, and Autonomous Vehicles: Tort Law and its Assimilation of Innovations,” 52 SANTA ClARA L. REV. 1241 (2012). ${ }^{11}$ Cf. James A. Kushner, Comparative Urban Planning LaW 243-44 (Carolina Academic Press 2003) (noting that environmental issues are inextricable from questions of growth, particularly where that "growth means increasing dependence on oil and energy production," and noting the opportunities for better planning and conservation, including "better architectural design" that "require[s] less energy," "planned open spaces utilizing water reclamation" that "could reduce water consumption and the cost of living," and more pedestrian- and transit-friendly housing that "could translate into public policy that does not threaten the environment as well as the economy.").
} 
building towns and cities that will not bleed slowly into the ecosystem around them, and that will thrive as different forms of transit come and go.

\section{Changing Transportation Technology}

In the roughly 250 years since its formation, the United States has seen a variety of transportation technologies. With each major shift in the way people travel, "the whole fabric of America's human geography was shredded and then rewoven in patterns determined by the particular way the new transport technology operated." ${ }^{12}$ Canals, streetcars, the railroad, and the automobile have all played a role in shaping the way that people live, ${ }^{13}$ primarily by increasing the speed and ease of travel, and opening up new areas for settlement. The consequent changes in national geography, and problems with congestion and sprawl, have played out in ways that may have "seemed unpredictable at the time"14 but which could potentially have been avoided through better planning. ${ }^{15}$

For instance, at their inception, "[i]t was assumed initially that motor-powered vehicles would merely replace horse-drawn vehicles," and that barns and stables could be used for overnight storage, with curbside parking available during the day. ${ }^{16}$ Many predicted that development of the automobile would reduce overall congestion because of its efficiencies over horse-drawn wagons. ${ }^{17}$ But the popularity of the automobile and the space each car consumed soon resulted in clogged streets. In response, many cities began requiring businesses to provide minimum parking spaces for

\footnotetext{
12 Peirce Lewis, "The Landscapes of Mobility," in The NATIOnAl RoAD 11, Karl Raitz, ed., Johns Hopkins Univ. Press (1996).

${ }^{13}$ Vukan Vuchic, Transportation for Livable Cities 5-6, Center for Urban Policy Research, Rutgers (1999); Peirce Lewis, "The Landscapes of Mobility," in The NATIONAl RoAd 11, 18, 24, Karl Raitz, ed., Johns Hopkins Univ. Press (1996).

${ }^{14}$ Peirce Lewis, "The Landscapes of Mobility," in The National RoAd 11, Karl Raitz, ed., Johns Hopkins Univ. Press (1996).

${ }^{15}$ Vukan Vuchic, Transportation for Livable Cities 9, Center for Urban Policy Research, Rutgers (1999) (noting that " $[\mathrm{t}] \mathrm{h}$ problem of excessive automobile traffic in U.S. cities was aggravated by failure to consider transportation as a system made up of different modes").

${ }^{16}$ John A. Jakle \& Keith A. Sculle, Lots of Parking: LAND Use in A Car Culture 19-21, Univ. of Virginia Press (2004).

${ }^{17}$ Id. at 19 .
} 
the use of their customers. ${ }^{18}$ Although it was perhaps not their initial motivation, minimum parking requirements have mandated and perpetuated sprawl development. Because parking is required, buildings have to be far apart; because the buildings are far apart, cars are required to reach them; because cars are required to reach them, more parking is required. ${ }^{19}$ This cycle is responsible in large part for the loss of density in American cities and suburbs, and its attendant costs.

Above all, minimum parking requirements are a "great planning disaster"—a case of policy recommendations untethered from their environmental and social costs. ${ }^{20}$ To avoid a similar disastrous fate for driverless cars, it is necessary to weigh their potential costs and benefits at the outset, even if impossible to predict the precise ways in which new transportation technologies will develop. $^{21}$ As electric and autonomous cars appear on the horizon, now is the time to use history as an example and think about possible impacts from and responses to these latest transit innovations.

\section{A. Electric Cars}

Electric cars have a long history in the United States. The vehicles competed with gasolinepowered vehicles for popularity in the early twentieth century. ${ }^{22}$ Struggles to provide a battery adequate for long distances stymied the electric car's progress, however, and its share of the market was quickly overtaken by the combustion engine. ${ }^{23}$ Although some attempts were made throughout the last century to make the electric vehicle more mainstream, ${ }^{24}$ automobile manufacturers appear

\footnotetext{
18 Donald Shoup, The High Cost of Free Parking 1-2, American Planning Association (2011).

19 See, e.g., John A. Jakle \& Keith A. Sculle, LOTS Of PARKING: LAND UsE IN A CAR Culture 3-4, Univ. of Virginia Press (2004).

20 Donald Shoup, The High Cost of Free Parking 127, American Planning Association (2011).

${ }^{21}$ Donald Shoup, The High Cost of Free Parking 6, American Planning Association (2011) (noting that "[a] simple projection is often a poor forecast because technology and policy can change").

22See, e.g., Daniel Sperling, Future Drive: Electric Vehicles and Sustainable Transportation 36, Island Press (1995) (noting that "at the turn of the century when motor cars were a new invention, electric vehicles outnumbered gasoline-powered vehicles”); Michael Brian Schiffer, TAKING CHARGE: THE ELECTRIC AUTOMOBILE IN AMERICA 57, Smithsonian Institution Press (1994) (stating that in 1899, “a wide assortment of electric passenger cars as well as commercial vehicles was being sold by more than a dozen firms.”).

${ }^{23}$ Michael Brian Schiffer, TAKING CHARge: The EleCTRIC AutOMOBILE IN AMERICA 75, Smithsonian Institution Press (1994).

24 See, e.g., Daniel Sperling, Future Drive: Electric Vehicles and Sustainable Transportation 36-37, Island Press (1995) (noting research by General Motors and Ford into electric vehicles in the 1960s, 1970s, and 1980s).
} 
not to have considered the possibility in earnest until 1990, when the California Air Resources Board released a Zero Emission Vehicle (ZEV) mandate. ${ }^{25}$ The ZEV mandate required that, in 1998, 2\% of new cars offered by large automobile manufacturers would have zero emissions; by 2003, the mandate increased to $10 \%,{ }^{26}$ and for 2017 , the requirement is $14 \% .{ }^{27}$ Incentivized by this requirement, a number of car manufacturers began marketing cars that used at least a hybrid of combustion and electric propulsion mechanisms. ${ }^{28}$ Early efforts to bring an all-electric car to market may have been sabotaged by car companies wary of abandoning profit centers attendant to the combustion engine, and concerned that acknowledgement of electric capabilities would subject them to permanently heightened emissions limitations. ${ }^{29}$ Now, however, all-electric vehicles are poised to make a more widespread introduction to the market as well. ${ }^{30}$

“The electric [car] does not solve every problem wrought by the automobile, but it solves a few problems well." 31 Chief among these is the problem of carbon dioxide emissions typically generated by standard combustion engines. Electric vehicles, or electric hybrid vehicles, are estimated to produce approximately half the amount of the current annual carbon dioxide emissions from gasoline powered vehicles, cutting the national average from approximately 11,500 pounds of

${ }^{25}$ Daniel Sperling, Future Drive: Electric Vehicles and Sustainable Transportation 37, Island Press (1995); Michael Brian Schiffer, TAKING Charge: The EleCtric Automobile In AMerica 176, Smithsonian Institution Press (1994).

${ }^{26}$ Michael Brian Schiffer, TAking ChArge: The Electric Automobile In America 176, Smithsonian Institution Press (1994).

${ }_{27}$ Section 1962.1, available at http://www.arb.ca.gov/msprog/zevprog/zevregs/1962.1_Clean.pdf (last visited Sept. 26, 2015).

${ }^{28}$ A Hybrid vehicle "employs a small internal combustion engine and an electric generator and battery to supplement battery power to the electronic motor drive, thereby increasing the vehicle's range and reducing the size of the engine and the battery pack." Richard C. Dorf, TECHNOlOGY, Humans AND SOCIETY: TOWARD A Sustainable WORLD 394 (Academic Press 2001). Hybrid vehicles reduce emissions appreciably, but are not zero emission vehicles. Id.

${ }_{29}$ See generally Chris Paine, et al. Who killed the electric car? Culver City, Calif: Sony Pictures Home Entertainment, 2006.

30 See, e.g., Brad Tuttle, "The Case for Buying an Electric Car is About to Get a Whole Lot Better," Money, TimE, available at http://time.com/money/3940042/nissan-leaf-chevy-bolt-tesla-driving-range/ (last visited August 12, 2015) (describing advancements in commercially available electric car technology).

${ }^{31}$ Michael Brian Schiffer, TAking Charge: The Electric Automobile In America 176, Smithsonian Institution Press (1994). 
carbon dioxide emitted annually from vehicles to around 5,800 pounds. ${ }^{32}$ While the unsustainability of many power sources means that electric vehicles are not an environmental panacea, ${ }^{33}$ widespread adoption of the vehicles would result in a meaningful decrease in greenhouse gas emissions. ${ }^{34}$ This is particularly true if the Environmental Protection Agency's Clean Power Plan ${ }^{35}$ results in expected increases in renewable energy sources. ${ }^{36}$

\section{B. Driverless Cars}

In very simple terms, self-driving vehicles "are those in which at least some aspects of a safety-critical control function (e.g., steering, throttle, or braking) occur without direct driver input." ${ }^{37}$ Driverless cars developed in two primary camps: those that communicate with other cars, the road, or both to navigate; and those that rely on an internal computer's assessment of road conditions. The former navigates via readings from satellites and maps of the terrain. ${ }^{38}$ The latter

\footnotetext{
32 See "Emissions from Hybrid and Plug-In Electric Vehicles," Alternative Fuels Data Center, Energy Efficiency \& Renewable Energy, U.S. Department of Energy, available at http://www.afdc.energy.gov/vehicles/electric_emissions.php (last visited Aug. 14, 2015).

33 See, e.g., Mikael Hård and Andreas Knie, "Getting Out of the Vicious Traffic Circle: Attempts at Restructuring the Cultural Ambience of the Automobile Throughout the 20th Century," in ELECTRIC VEHICLES: SOCIO-ECONOMIC Prospects and Technological Challenges 40, Robin Cowan \& Steffan Hultén, eds. (2001) (noting that "representatives of environmental movements, who have generally been strongly opposed to the gasoline engine, have tended to disqualify the electric car as the 'coal car' or the 'atomic automobile" given that electric power has not been generated in a sustainable manner).

34 See, e.g., Alternative Fuels Data Center, United States Department of Energy, Energy Efficiency \& Renewable Energy, "Emissions from Hybrid and Plug-In Electric Vehicles," available at http://www.afdc.energy.gov/vehicles/electric_emissions.php (noting that, even taking into account "well-to-wheel" emissions for electric vehicles, they contribute approximately half of the emissions of conventional gas vehicles). 3580 Fed. Reg. 64,661 (Oct. 23, 2015).

36 See "More Electric Cars than Ever on Greenest Vehicles List," greenercars.org (Jan. 26, 2016), available at http://greenercars.org/news/press-releases/more-electric-cars-ever-greenest-vehicles-list (last visited Feb. 5, 2016) (noting that "the electricity sector is slated to become cleaner . . . thanks to the Clean Power Plan").

${ }^{37}$ National Highway Traffic Safety Administration, Preliminary Statement of Policy Concerning Automated Vehicles, available at

http://www.nhtsa.gov/About+NHTSA/Press+Releases/U.S.+Department+of+Transportation+Releases+Policy+on +Automated+Vehicle+Development (last visited July 28, 2015). The National Highway Traffic Safety Administration has designated four levels of automation, ranging from function-specific automation, such as electronic stability control or pre-charged brakes, all the way to full self-driving automation, for which there is no expectation that the driver will be available for control at any time during the trip.

38 See Burkhard Bilger, "Auto Correct: Has the Self-Driving Car At Last Arrived?," THE New Yorker (Nov. 25, 2013) (describing processes by which autonomous vehicles were developed).
} 
relies on satellites, lasers, and a computer program through which the vehicle is painstakingly trained to "recognize" hazards and other elements of driving. ${ }^{39}$

Cars that drive without human control have long been part of the popular imagination. The 1940 World's Fair included an exhibition called "Futurama" that depicted the world of 1960 as one of automated highways and cars capable of making a trip across the United States in 24 hours. ${ }^{40}$ Crowds waited in long lines to be shown a world where cars operated on a sophisticated track across the country, and where traffic and congestion had been eliminated. This, promised Norman Bel Geddes, architect of Futurama (and GM, its sponsor ${ }^{41}$ ), was the future in two decades. From there, progress came slowly but steadily. The 1960s of Futurama did not come to pass, but that decade brought dedicated research into driver assistance systems and autonomous vehicles. ${ }^{42}$ Self-driving cars were introduced in some forms by the 1970 s, ${ }^{43}$ and by the 1980 s, computing and sensing performance had improved sufficiently to allow for better driver assistance systems. ${ }^{44}$ The $1990 \mathrm{~s}$ brought a big breakthrough in the form of adaptive cruise control, and other automated systems such as emergency braking and pedestrian detection. ${ }^{45}$

None of that compares to advances made since the turn of the twenty-first century. Much of the current spate of innovation in driverless cars was jump started through a contest run by the Defense Advanced Research Projects Agency (DARPA), an agency of the United States Department of Defense dedicated to development of emerging technologies for use by the military. In an attempt to advance driverless vehicle technology, DARPA sponsored driverless car races known as

\footnotetext{
${ }^{39} I d$.

40 See Norman Bel Geddes, Magic Motorways, Book Jacket, 8 (Random House 1940).

41 See Charles Montgomery, Happy City: Transforming Our Lives Through Urban Design 73, New York: Farrar, Straus \& Giroux (2013).

42 Dr. Sven A. Beiker, "Legal Aspects of Autonomous Driving," 52 SANTA Clara L. REv. 1145, 1146 (2012).

43 Adam Fisher, "Inside Google’s Quest to Popularize Self-Driving Cars," POPUlAR ScIENCE (Sept. 13, 2013), available at http:/ /www.popsci.com/cars/article/2013-09/google-self-driving-car (last visited July 28, 2015).

44 See Dr. Sven A. Beiker, "Legal Aspects of Autonomous Driving," 52 SANTA ClarA L. ReV. 1145, 1146 (2012).

45 Dr. Sven A. Beiker, "Legal Aspects of Autonomous Driving," 52 SANTA ClarA L. REV. 1145, 1148 (2012).
} 
"Grand Challenges" in 2004, 2005, and 2007. ${ }^{46}$ These Challenges inspired rapid advances in driverless car technology. ${ }^{47}$ In April 2015, a car drove from San Francisco to New York City in 9 days, doing $99 \%$ of the driving on its own. ${ }^{48}$ Most automakers "expect to have cars capable of handling themselves in stop and go traffic and on the highway within three to five years. Cars capable of navigating more complex urban environments will follow in the years beyond that, while fully autonomous vehicles are expected to be commonplace by 2040." ${ }^{49}$ Others predict more comprehensive autonomous features in vehicles by $2020,41 \%$ of the national vehicle fleet with some type of autonomous driving mode by 2030 , and $75 \%$ of vehicles with fully automated functions by $2035 .{ }^{50}$ A large number of major automobile manufacturing companies have announced plans to incorporate driverless technology into upcoming vehicles. ${ }^{51}$ Regulators are also responding to these advances; the National Highway Traffic Safety Administration intends to issue

\footnotetext{
${ }^{46}$ Adam Fisher, "Inside Google's Quest to Popularize Self-Driving Cars," POPUlAR SCIENCE (Sept. 13, 2013), available at http://www.popsci.com/cars/article/2013-09/google-self-driving-car (last visited Sept. 26, 2015).

47 See, e.g., Alex Davies, "This is Big: A Robo-Car Just Drove Across the Country," WiRED (April 3, 2015) (noting that, at the 2004 DARPA Grand Challenge, the vehicles tried to complete a 150-mile course. The best result was 7,32 miles, "and that vehicle got stuck and caught fire." By the 2005 Grand Challenge, five vehicles completed a 132-mile course in seven hours.).

48 Alex Davies, "This is Big: A Robo-Car Just Drove Across the Country," WIRED (April 3, 2015). This is still a great deal removed from the 24-hour trip by autonomous vehicle from the Atlantic Coast to San Francisco predicted in Norman Bel Geddes's Magic Motorways, the book accompanying the "Futurama" exhibit. See Norman Bel Geddes, MAGIC MOTORWAYS 151-164 (Random House).

49 Alex Davies, "This is Big: A Robo-Car Just Drove Across the Country," Wired (April 3, 2015).

${ }^{50}$ David Alexander and John Gartner, Navigant Research, "Executive Summary: Autonomous Vehicles-Self-Driving Vehicles, Advanced Driver Assistance Systems, and Autonomous Driving Features: Global Market Analysis and Forecast," 3Q 2014, available at https://www.navigantresearch.com/research/autonomous-vehicles (last visited July 28, 2015); see also Navigant Research, "Autonomous Vehicles Will Surpass 95 Million in Annual Sales by 2035” (August 21, 2013), available at http://www.navigantresearch.com/newsroom/autonomous-vehicles-will-surpass-95-million-inannual-sales-by-2035 (last visited July 28, 2015); Alex Davies, "Volvo Will Test Self-Driving Cars With Real Customers in 2017," WIRED (Feb. 23, 2015) (noting that Nissan and Mercedes have given themselves a 2020 deadline for putting cars with autonomous features on the market).

51 See, e.g., Kirsten Korosec, "Elon Musk Says Tesla Vehicles Will Drive Themselves in Two Years," FortunE (Dec. 21, 2015), available at http:/ / fortune.com/2015/12/21/elon-musk-interview/ (last visited Dec. 22, 2015); Charles Fleming, "Ford driverless car to hit California roads," LOS ANGELES TIMES (Dec. 15, 2015), available at http://www.latimes.com/business/autos/la-fi-hy-ford-driverless-car-to-hit-california-roads-20151215-story.html (last visited Dec. 22, 2015); Victor Luckerson, "Microsoft Is Developing Driverless Car Technology With Volvo," TimE (Nov. 20, 2015), available at http://time.com/4122084/microsoft-diverless-car-volvo/ (last visited Dec. 22, 2015); Mike Ramsey, "Nissan Speeds Ahead of Rivals With Plans for Driverless Car," THE WALl StreEt Journal (Oct. 29, 2015), available at http:/ /www.wsj.com/articles/nissan-speeds-ahead-of-rivals-with-plans-for-autonomous-car-1446121737 (last visited Dec. 22, 2015); “Toyota promises driverless cars on roads by 2020," BBC NEWS (Oct. 7, 2015), available at http://www.bbc.com/news/technology-34464450 (last visited Dec. 22, 2015).
} 
"best-practice guidance to industry on establishing principles of safe operation for fully autonomous vehicles" in $2016 .^{52}$

\section{Autonomous Vehicles, For Better and For Worse}

Current advances in automobile technology are a feat of human engineering. Along with marvel at their ingenuity, however, these automobiles should inspire reflection about the likely shape of a driverless future. We need only to look at the difference between the landscape of the United States at its inception and today to appreciate that a relatively brief span of time can lead to unimaginable changes in development patterns based on shifting transportation technologies. Acknowledging the potential benefits of new transit along with its possible costs is important for a complete understanding of how driverless cars could impact the world.

\section{For Better}

Driverless cars are likely to have many benefits. ${ }^{53}$ First, autonomous vehicles are expected to be quite literally lifesaving. In the United States, car accidents killed over 30,000 people in $2013,{ }^{54}$ and " $[\mathrm{t}]$ he medical costs of car collisions are the largest single component of the health care costs" in the country. ${ }^{55}$ As it may well be that "[o]f the ten million accidents that Americans are in every year, nine and a half million are their own damn fault," likely to make travel by car much safer. These safety improvements may not be fully felt until a

52 "DOT/NHTSA Policy Statement Concerning Automated Vehicles," 2016 Update to "Preliminary Statement of Policy Concerning Automated Vehicles" (Jan. 14, 2016), available at

http://www.nhtsa.gov/staticfiles/rulemaking/pdf/Autonomous-Vehicles-Policy-Update-2016.pdf (last visited Feb. 8, 2016).

53 National Highway Traffic Safety Administration, Preliminary Statement of Policy Concerning Automated Vehicles, available at http://orfe.princeton.edu/ alaink/SmartDrivingCars/Automated_Vehicles_Policy.pdf (last visited August 4,2016 ) (noting that the benefits of driverless cars include not only safety, but also "[v]ehicle control systems that automatically accelerate and brake with the flow of traffic can conserve fuel more efficiently than the average driver. By eliminating a large number of vehicle crashes, highly effective crash avoidance technologies can reduce fuel consumption by also eliminating the traffic congestion that crashes cause every day on our roads. Reductions in fuel consumption, of course, yield corresponding reductions in greenhouse gas emissions.").

54 “Accidents or Unintentional Injuries," Final Data for 2013, Center for Disease Control and Prevention, available at http://www.cdc.gov/nchs/fastats/accidental-injury.htm (last visited September 14, 2015).

55 James A Kushner., Healthy Cities: The Intersection of Urban Planning, LAw and Health vii (Carolina Academic Press 2007).

${ }^{56}$ Burkhard Bilger, “Auto Correct: Has the Self-Driving Car At Last Arrived?,” THE NEW Yorker (Nov. 25, 2013). 
majority of vehicles on the road are fully autonomous, given the potential for dangerous interactions of human reactions and computer programming. ${ }^{57}$ And, to be sure, driverless cars are not failsafe; the first known death due to an error of an autopilot system occurred in May $2016 .{ }^{58}$ Nonetheless, driverless cars are anticipated to result in many fewer fatalities than human-operated vehicles.

Air pollution is also likely to decrease in a world of driverless vehicles. Self-driving cars are likely to encourage development of electric car technology by opening up the possibility of centralized charging stations to which cars could drive themselves when not in use. As noted above, electric cars are responsible for many fewer emissions than gasoline-powered vehicles. But even autonomous vehicle technology alone is expected to offer air quality benefits. For instance, development of driverless cars is predicted to incentivize fuel efficiency because of the expected increase in miles traveled for each individual car. ${ }^{59}$ Moreover, according to a 2007 survey, traffic congestion resulted in 2.8 billion gallons of fuel burned annually. ${ }^{60}$ Traffic made up of autonomous vehicles is expected to flow more efficiently than in the past, which will contribute to greater fuel efficiency and emissions reductions. ${ }^{61}$ Such air quality improvements have important environmental and social justice impacts. An elimination of emissions from vehicles could be an important part of controlling climate change, as "[t] he combustion of fossil fuels such as gasoline and diesel to transport people and goods [was] the second largest source of $\mathrm{CO}_{2}$ emissions" in the United States in 2014, "accounting for about $31 \%$ of total U.S. $\mathrm{CO}_{2}$ emissions and $25 \%$ of total U.S. greenhouse

\footnotetext{
57 See, e.g., Jim Kerstetter, "Daily Report: Google’s Driverless Car Learns to Navigate an Imperfect World," Bits, THE NEW YORK TIMES (September 2, 2015), available at http://bits.blogs.nytimes.com/2015/09/02/daily-report-googlesdriverless-car-learns-to-navigate-an-imperfect-world/?_r=0 (last visited September 14, 2015).

58 See Joan Lowy \& Tom Krisher, Tesla driver's death using car's 'Autopilot' probed by NHTS A, THE WASHINGTON POST (July 1, 2016), https://www.washingtonpost.com/politics/tesla-driver-killed-in-crash-while-using-carsautopilot/2016/06/30/29d740b6-3f22-11e6-9e16-4cf01a41decb_story.html ${ }^{59}$ Jeffery B. Greenblatt \& Susan Shaheen, “Automated Vehicles, On-Demand Mobility, and Environmental Impacts," Transportation, Curr. Sustainable Renewable Energy Rep. (2015) 2:74-81, at 79.

${ }^{60}$ Dr. Sven A. Beiker, "Legal Aspects of Autonomous Driving," 52 SANTA Clara L. REV. 1145, 1150 (2012).

${ }^{61}$ Adam Fisher, "Inside Google’s Quest to Popularize Self-Driving Cars," POPULAR SCIENCE (Sept. 13, 2013), available at http:/ / www.popsci.com/cars/article/2013-09/google-self-driving-car (last visited July 28, 2015).
} 
gas emissions." ${ }^{2} 2$ These improvements should therefore have important positive impacts for ecosystem health, as well as for environmental justice. ${ }^{63}$

Driverless cars also have the potential for many positive impacts on both the fact and experience of time in traffic. As noted, current estimates are that the average commuter spends forty-two hours in traffic congestion each year. ${ }^{64}$ But the more efficient flow of vehicles made possible by driverless cars may mean that "traffic jams become a thing of the past[.]" ${ }^{65}$ The elimination of cognitive requirements while in those cars also frees up travel time for productivity or rest, ${ }^{66}$ lowering the time-cost of travel. Further, autonomous vehicles will provide greater accessibility to segments of the population who are currently unable to drive but who live in areas where private vehicles are the only mode of transportation, including seniors, teenagers, and the disabled. ${ }^{67}$

At a more abstract level, driverless cars may also spell the end of private vehicle ownership, or may at least help it on its way. Individual automobiles, and the freedom of movement that they

62 “Overview of Greenhouse Gases," Climate Change, U.S. Environmental Protection Agency, available at http://www3.epa.gov/climatechange/ghgemissions/gases/co2.html (last visited Sept. 26, 2015).

${ }^{63}$ Environmental justice refers to "the fair treatment of people of color in the distribution of environmental benefits and burdens.” See Alice Kaswan, “Environmental Laws: Grist for the Equal Protection Mill,” 70 U. Colo. L. Rev. 387,389 (1999). Reduction of harmful emissions implicates environmental justice because populations of racial minority are currently "more likely to live in areas with reduced air quality when compared with whites." See Robert D. Bullard, "Addressing Urban Transportation Equity in the United States," in BREAKTHROUGH COMMUNITIES: SUSTAINABILITY and Justice in the NeXt American Metropolis 54-55, M. Paloma Pavel, ed. (MIT Press 2001).

${ }^{64}$ Dr. Sven A. Beiker, "Legal Aspects of Autonomous Driving," 52 SANTA Clara L. REV. 1145, 1150 (2012).

65 Adam Fisher, "Inside Google’s Quest to Popularize Self-Driving Cars," POPUlAR SCIENCE (Sept. 13, 2013), available at http:/ /www.popsci.com/cars/article/2013-09/google-self-driving-car (last visited July 28, 2015).

66 See, e.g., Dan Neil, "Who's Behind the Wheel? Nobody," THE WALL STREET JOURNAL, Journal Reports: Energy Big Issues (Sept. 24, 2012), available at http:/ /www.wsj.com/articles/SB10000872396390443524904577651552635911824

(last visited Jan. 5, 2015) (noting the lack of productivity for drivers during their commutes).

67 See Bryant Walker Smith, "Managing Autonomous Transportation Demand," 52 SANTA ClarA L. REV. 1401,1409 (2012) ("Self-driving cars that do not need human drivers or monitors may substantially increase mobility for those who cannot (legally) drive themselves because of youth, age, disability, or incapacitation); see also, e.g., James A. Kushner,

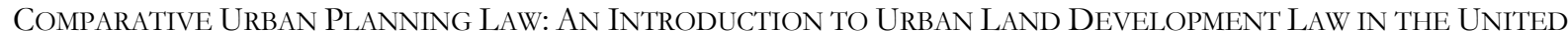
States Through the Lens of Comparing the ExperienCe of Other NATIONS 3-4 (Carolina Academic Press 2003) (noting that where lifestyles are automobile centered, " $[t]$ he elderly, the young, and the disabled, unable to drive, are captive in their homes and dependent on others for mobility"). 
represent, have long been interwoven with a sense of identity for a number of Americans. ${ }^{68}$ That connection to the automobile is likely responsible in part for much of the resistance to mass transit options and land use controls that counteract suburban expansion. Many predict that driverless cars will result in decreased private vehicle ownership because of the ease of car-sharing in a world where the car can transport itself among users. ${ }^{69}$ And even for those who choose to privately own driverless cars, those vehicles may serve a psychological role in bringing about a more gradual shift in thinking about private car ownership. By removing the human element from the chain—a car, not driving, is how you get around-the autonomous vehicle may help to break the tie between identity and personal automobile ownership. ${ }^{70}$ A reconceptualization of the human relationship to cars may make it possible over time to encourage more efficient, less land-intensive forms of transportation, and may help to eliminate reliance on personal ownership of vehicles altogether.

\section{For Worse}

For all of those benefits, self-driving cars may also have a substantial downside. A recent study by EPA observed a leveling off of the increase in vehicle miles traveled (VMT) per year in the

\footnotetext{
68 See Jake Blumgart, "Whither the Driverless Car?" (Jan. 23, 2013), in Transit Evolved, Next City, 22 (2016), available at https:// nextcity.org/ebooks/view/transit-evolved ("Cars have long been indicative of freedom, status symbols connected to what it means to be American”); but see Dan Neil, "Who's Behind the Wheel? Nobody," THE WALL STREET JOURNAL, Journal Reports: Energy Big Issues (Sept. 24, 2012), available at http://www.wsj.com/articles/SB10000872396390443524904577651552635911824 (last visited Jan. 5, 2015) (objecting to notion of car-centered identity as a manufacturers' construct and stating that a majority of Americans view car ownership as an "expensive obligation and necessity" and a "brutal tax.").

${ }^{69}$ Some proponents of the autonomous vehicle highlight the potential for a shared fleet of vehicles to replace private vehicle ownership as the predominant means of transport by automobile. See, e.g., "Google's X-Man: A Conversation with Sebastian Thrun," Comments, 92 FOREIGN AfFAIRS 6, p. 4 (2013).

70 See, e.g., Dan Neil, "Could Self-Driving Cars Spell the End of Ownership?," THE WALL STREET JOURNAL (Dec. 1, 2015), available at http:/ / www.wsj.com/ articles/could-self-driving-cars-spell-the-end-of-ownership-1448986572?tesla =y (last visited Jan. 5, 2016); but see Levinson, David, 16 MINN. J.L. SCI. \& TECH. 787, 802 (2015) (noting that shared vehicle services will work better in urban areas than rural ones). Any such trend may first require overcoming personal preferences that could serve as a barrier to adoption of self-driving cars in any form-reluctance to forfeit control of cars and/or enjoyment of driving. See Jane Bierstedt, et al., "Effects of Next-Generation Vehicles on Travel Demand and Highway Capacity," Fehr \& Peers, FP Think Working Group, 9 (January 2014), available at http://orfe.princeton.edu/ alaink/Papers/FP_NextGenVehicleWhitePaper012414.pdf (last visited Jan. 10, 2016); see also Dorothy J. Glancy, "Autonomous and Automated and Connected Cars-Oh My! First Generation Autonomous Cars in the Legal Ecosystem," 16 MinN. J.L. SCI. \& TECH. 619, 633 (2015) (“Car buyers whose adolescence was culminated by acquiring a driver's license may not be as eager to leave car operation to the car.").
} 
United States. ${ }^{71}$ The report theorized that "travel demand might have reached a saturation point as drivers are unwilling to devote more time to travel, infrastructure improvements no longer allow substantial speed increases, and the marginal benefits of additional trips or travel to additional destinations are not worth the marginal cost."72 Economists too have proposed a "reduced tolerance for commuting" as part of the reason for the increase in urban home values. ${ }^{73}$ Under this theory, the limitations of current transportation technology have brought us to a point of VMT saturation $^{74}$ that has contributed to the renewed urban growth of the past several decades. That growth, changing demographics in the United States, and other factors have led to a decline in traditional suburban development's popularity. ${ }^{75}$

Driverless cars change much of that. Historically, new transportation technologies lead to larger metropolitan areas, ${ }^{76}$ and "time saved from mobility gains is used mostly in additional distance between home and workplace." 77 With the addition of productive time in the car, the "time-cost of

\footnotetext{
${ }^{71}$ United States Environmental Protection Agency, "Our Built and Natural Environments: A Technical Review of the Interactions Among Land Use, Transportation, and Environmental Quality," $2^{\text {nd }}$ Edition (2013) at 26, available at http://www2.epa.gov/sites/production/files/2014-03/documents/our-built-and-natural-environments.pdf (last visited July 28, 2015).

72 United States Environmental Protection Agency, "Our Built and Natural Environments: A Technical Review of the Interactions Among Land Use, Transportation, and Environmental Quality," $2^{\text {nd }}$ Edition (2013) at 26-27, available at http://www2.epa.gov/sites/production/files/2014-03/documents/our-built-and-natural-environments.pdf (last visited July 28, 2015).

${ }^{73}$ Eric Jaffe, "Why the Wealthy Have Been Returning to City Centers," CityLab (Nov. 17, 2015), available at http://www.citylab.com/commute/2015/11/why-the-wealthy-have-been-returning-to-the-city-center/416397/ (last visited Jan. 5, 2016).

74 See Levinson, David, "Climbing Mount Next: The Effects of Autonomous Cars on Society,” 16 MINN. J.L. SCI. \& TECH. 787, 792 (2015).

75 See, e.g, Nicholas A. Phelps, "Introduction: From the Modern Suburb to the Post-Suburb of a Second Modernity," in SEquel to Suburbia: Glimpses of AmeriCA’s Post-Suburban Future 3, Cambridge: MIT Press (2015) (noting " $t$ ] here is certainly enough in present academic and popular debates to realize that much of the shine has come off the outer suburbs of [the] first modernity"); Leigh Gallagher, THE END OF THE SUBURBS: WHERE THE AMERICAN DREAM IS Moving 192, Portfolio/Penguin: New York (2013) (listing factors that may "point to the end of the suburbs as we know them"); see also Jeff Speck, Walkable City: How Downtown CAN SAVE America, One STEP AT A Time 21-28, New York: Farrar, Straus and Giroux (2012) (describing how demographic trends and shifting preferences are increasing demand for pedestrian-friendly communities, and decreasing demand for traditionally car-dependent suburbs).

${ }^{76}$ David Levinson, “Climbing Mount Next: The Effects of Autonomous Cars on Society,” 16 MiNN. J.L. SCI. \& TECH. 787, 803 (2015).

77 David Levinson, "Climbing Mount Next: The Effects of Autonomous Cars on Society," 16 MINN. J.L. SCI. \& TECH. 787, 803-04 (2015).
} 
these trips approaches zero," 78 resulting in reduced pressure for workers to live near the city center. ${ }^{79}$

With traffic and travel time no longer a deterrent to living far outside the urban core, "autonomous

driving may ... encourage suburban sprawl by increasing the acceptable commuting distance." 80

A 2013 report by EPA estimates that the U.S. population will increase 42\% between 2010

and $2050 .^{81}$ EPA estimates that these figures will require the development of 52 million new

housing units, and many billions of square feet of nonresidential space. ${ }^{82}$ With an expansion of the

market for residential locations created by driverless cars, developers are likely to press for

construction at the urban or suburban fringe, where land has been historically cheap. ${ }^{83}$ This cycle is

self-perpetuating, as "[a]uto use expands to cover the sprawling development patterns that separate

homes from everything else," ${ }^{\prime 4}$ and expansions of roads due to increased demand open additional

areas to development. ${ }^{85}$

\footnotetext{
${ }^{78}$ Bryant Walker Smith, "Managing Autonomous Transportation Demand," 52 SANTA Clara L. Rev. 1401, 1410 (2012). This is particularly true given that some people do not view time spent commuting as unproductive time. See Selima Sultama and Joe Weber, "Journey-to-Work Patterns in the Age of Sprawl: Evidence from Two Midsize Southern Metropolitan Areas," 59:2 THE Professional GeOgraPher 193, 195 (2007) (citing evidence that even with existing vehicle technology, "people may derive pleasure from the experience of commuting, and will not necessarily perceive a long commute as a burden.").

79 Adeel Lari, Frank Douma \& Ify Onyiata, "Self-Driving Vehicles and Policy Implications: Current Status of Autonomous Vehicle Development and Minnesota Policy Implications," 16 MinN. J. L. SCI. \& TECH. 735, 757 (2015). ${ }^{80}$ Bryant Walker Smith, "Managing Autonomous Transportation Demand," 52 SANTA CLARA L. REV. 1401, 1417 (2012); David Levinson, "Climbing Mount Next: The Effects of Autonomous Cars on Society," 16 MINN. J.L. SCI. \& TECH. 787, 804 (2015)(“[A]s acceptable trip distances increase, we would expect a greater spread of origins and destinations (pejoratively, sprawl) ....").

${ }^{81}$ United States Environmental Protection Agency, "Our Built and Natural Environments: A Technical Review of the Interactions Among Land Use, Transportation, and Environmental Quality," $2^{\text {nd }}$ Edition (2013) at 31, available at http://www2.epa.gov/sites/production/files/2014-03/documents/our-built-and-natural-environments.pdf (last visited July 28, 2015); see also Freilich Robert H. and Neil M. Popowitz, "The Umbrella of Sustainability: Smart Growth, New Urbanism, Renewable Energy and Green Development in the 21st Century," 42 THE URBAN LAWYER 1, 2-3 (2010) (estimating that the United States population will reach 350 million by 2025, which is an increase of 67 million people since 2000).

82 United States Environmental Protection Agency, "Our Built and Natural Environments: A Technical Review of the Interactions Among Land Use, Transportation, and Environmental Quality," 2nd Edition (2013) at 31, available at http://www2.epa.gov/sites/production/files/2014-03/documents/our-built-and-natural-environments.pdf (last visited July 28, 2015).

83 See, e.g. James A. Kushner, The Post-Automobile City: Legal Mechanisms to Establish the PedestrianFRIENDLY CiTY 28 (Carolina Academic Press 2004).

${ }^{84} \mathrm{John}$ R. Nolon, Protecting the Environment Through Land Use LaW: Standing Ground 14-15 (ELI Press 2014).

${ }^{85}$ Bryant Walker Smith, "Managing Autonomous Transportation Demand," 52 SANTA CLARA L. REV. 1401, 1418

(2012). Autonomous vehicles are expected to increase the vehicle capacity of existing roads. Id. at 1412. This
} 
“[O]nce built, highways allow easy access to land that was previously difficult to reach,", and "if you expand people's ability to travel, they will do it more, living farther away from where they work and therefore being forced to drive into town." ${ }^{87}$ As additional roads are constructed, more vehicles will fill them. ${ }^{88}$ The pattern of mounting traffic produced by additional road capacity is known as induced demand. ${ }^{89}$ Normally, induced demand serves to harness growth to some degree, as the addition of roads and vehicles do not result in shorter travel times. As noted, however, if "the [well-connected] car provides an environment that is as enjoyable or productive as the home or office, the time-cost of motor vehicle travel could . . drop substantially."90 This drop in time cost can again "encourage more dispersed land use patterns that, in turn, [may] increase trip lengths and vehicle dependency, leading to a permanent increase in travel demand."91

The pressure for additional roads due to autonomous vehicles may be a question not only of dispersed land patterns, but also of the increased numbers of cars on the road at any given time. Autonomous cars allow demographic groups who are currently unable to drive to travel safely by

expansion of road capacity may reduce the cost of each trip, and create greater short- and long-term demand for trips by car. Id. at 1410.

${ }^{86}$ William W. Buzbee, "Urban Sprawl, Federalism, and the Problem of Institutional Capacity,” 68 FORDHAM L. REV. 57, 79 (2000).

${ }^{87}$ Adam Mann, "What's Up With That: Building Bigger Roads Actually Makes Traffic Worse,” Science, WIRED (June 17, 2014), http://www.wired.com/2014/06/wuwt-traffic-induced-demand/.

${ }^{88}$ In the short term, increased road capacity "lead[s] to people making more trips, increasing trip length, changing the time of travel, or switching from transit or carpools to driving alone because of improved traffic conditions." United States Environmental Protection Agency, "Our Built and Natural Environments: A Technical Review of the Interactions Among Land Use, Transportation, and Environmental Quality," 2nd Edition (2013) at 28, available at

http://www2.epa.gov/sites/production/files/2014-03/documents/our-built-and-natural-environments.pdf (last visited July 28, 2015).

${ }^{89}$ United States Environmental Protection Agency, "Our Built and Natural Environments: A Technical Review of the Interactions Among Land Use, Transportation, and Environmental Quality,” $2^{\text {nd }}$ Edition (2013) at 27-28, available at http://www2.epa.gov/sites/production/ files/2014-03/documents/our-built-and-natural-environments.pdf (last visited July 28, 2015); see also Adam Mann, "What's Up With That: Building Bigger Roads Actually Makes Traffic Worse," Science, WirED (June 17, 2014), http://www.wired.com/2014/06/wuwt-traffic-induced-demand/ (citing a 2009 study finding a perfect one-to-one relationship between the amount of new roads and the total number of miles driven). ${ }^{90}$ Bryant Walker Smith, "Managing Autonomous Transportation Demand,” 52 SANTA CLARA L. REV. 1401, 1410 (2012).

${ }^{91}$ United States Environmental Protection Agency, "Our Built and Natural Environments: A Technical Review of the Interactions Among Land Use, Transportation, and Environmental Quality," $2^{\text {nd }}$ Edition (2013) at 28, available at http://www2.epa.gov/sites/production/files/2014-03/documents/our-built-and-natural-environments.pdf (last visited July 28, 2015). 
private automobile. ${ }^{92}$ These groups include seniors, children, and those otherwise unable to operate a vehicle. EPA estimates that the number of seniors over 65 will double between 2010 and $2050 .{ }^{93}$ Moreover, the number of children ranging even from thirteen to fifteen-just below the current legal age for driving in most states—is over 12 million based on a 2014 estimate. ${ }^{94}$ Given these additions, the potential for an overall rise in the number of vehicle trips is clear. ${ }^{95}$ Widespread adoption of driverless cars is predicted to decrease the absolute total of unique vehicles on the road, ${ }^{96}$ given the capacity for shared fleets, but is likely to increase overall VMT. ${ }^{97}$

These predictions mean that the driverless world could be one of reduced density, an increased road network, and increased miles traveled. As “[y]esterday's luxuries” in terms of road capacity and ease of travel are "converted into today's necessities," 98 the increased reliance on automobiles and their accompanying infrastructure may become firmly entrenched. In this way,

\footnotetext{
92 See, e.g., Daniel J. Fagnant \& Kara M. Kockelman, Preparing a Nation for Autonomous Vehicles: Opportunities, Barriers and Policy Recommendations, Eno Center for Transportation (October 2013), available at https://www.enotrans.org/wpcontent/uploads/2015/09/AV-paper.pdf (last visited Jan. 4, 2016) ("[Autonomous vehicles] may provide mobility for those too young to drive, the elderly and the disabled, thus generating new roadway capacity demands."). ${ }^{93}$ John R. Nolon, Protecting the Environment Through Land Use Law: Standing Ground 13 (ELI Press 2014).

94 "Annual Estimates of the Resident Population by Single Year of Age and Sex for the United States: April 1, 2010 to July 1, 2014,” 2014 Population Estimates, United States Census Bureau, available at http://factfinder.census.gov/faces/tableservices/jsf/pages/productview.xhtml?src=bkmk (last visited Sept. 26, 2015). This number is cited only as an estimate of increased demand for private vehicles. Autonomous vehicle usage may extend beyond this age subset.

${ }^{5}$ See Jane Bierstedt, et al., "Effects of Next-Generation Vehicles on Travel Demand and Highway Capacity," Fehr \& Peers, FP Think Working Group (January 2014) at 4, available at http://orfe.princeton.edu/ alaink/Papers/FP_NextGenVehicleWhitePaper012414.pdf (last visited Jan. 10, 2016) (noting that "availability of robo-chauffeuring for those who would otherwise not be permitted to drive" is likely to increase VMT per capita).

${ }_{96}$ See Keith Naughton, "Driverless Cars May Cut U.S. Auto Sales 40\%, Barclays Says," BloombergBusiness (May 20, 2015), available at http://www.bloomberg.com/news/articles/2015-05-19/driverless-cars-may-cut-u-s-auto-sales-by-40barclays-says (last visited Jan. 8, 2016) (noting that while U.S. vehicle ownership rates will fall, driverless cars will travel twice as many miles as current automobiles during the course of the day); see also Kirsten Korosec, "The Number of Miles Cars Travel is About to Explode," Fortune (Nov. 17, 2015), available at http://fortune.com/2015/11/17/la-autoshow-vehicle-miles/ (last visited Jan. 8, 2016) (citing KPMG report predicting that "U.S. cars will travel one trillion additional miles annually by 2050").

${ }^{77}$ See, e.g., Daniel J. Fagnant \& Kara M. Kockelman, Preparing a Nation for Autonomous Vebicles: Opportunities, Barriers and Policy Recommendations, Eno Center for Transportation (October 2013), available at https://www.enotrans.org/wpcontent/uploads/2015/09/AV-paper.pdf (last visited Jan. 4, 2016) (noting that many of the expected changes from autonomous vehicles "point toward more vehicle-miles traveled (VMT) and automobile-oriented development .... [a]dded VMT may bring other problems related to high automobile use ...."). ${ }_{98}$ Cf. Norman Bel Geddes, MAGIC Motorways 290 (Random House 1940).
} 
autonomous cars may contribute to renewed sprawl, further untethered from cities. In contrast to the myriad benefits of driverless cars, this kind of increase in growth is likely to lead to a variety of environmental problems.

\section{a. Resource Pressures}

First, an increase in demand for undeveloped land will place pressure on already-scarce resources. A 2010 study by the United States Forest Service "forecasts that between 1997 and 2060, 60 to 86 million acres of rural land (as much as the size of New Mexico) will be developed, and between 24 and 38 million acres of forests (as much as the size of Florida), 19 and 28 million acres of cropland (as much as the size of Tennessee), and 8 and 11 million acres of rangeland (as much as the size of Vermont and New Hampshire together) will be lost." 99 These predictions do not incorporate any predictions about driverless car technology. Pressure from autonomous vehicles for additional roads and development has the potential to accelerate this trend, with potentially devastating consequences for ecosystem health.

Low-density development puts an enormous strain on water supplies. First, sprawl development results in the consumption of large amounts of water, particularly when combined with personal lawns and other water-intensive practices. ${ }^{100}$ Ultimately, "there is not enough water to indefinitely sustain the expansion of American cities using water within their watershed." ${ }^{101}$ Climate change may exacerbate that scarcity, as rising temperatures result in higher rates of evaporation and

\footnotetext{
${ }^{99}$ United States Environmental Protection Agency, "Our Built and Natural Environments: A Technical Review of the Interactions Among Land Use, Transportation, and Environmental Quality," $2^{\text {nd }}$ Edition (2013) at 32, available at http://www2.epa.gov/sites/production/ files/2014-03/documents/our-built-and-natural-environments.pdf (last visited July 28, 2015).

100 See, e.g., Sarah Schindler, Banning Lawns, 82 GEO. WASH. L. REV. 394, 396 (2013) ("[l]awns . . consume up to sixty percent of potable municipal water supplies in Western cities and up to thirty percent in Eastern cities").

${ }^{101}$ Benjamin Houston \& Noah D. Hall, "Managing Demand for Water," in THE LAW Of AdAPTATION TO Climate

CHANGE, Michael B. Gerrard \& Katrina Fischer Kuh, eds., ABA Press (2012).
} 
less precipitation. ${ }^{102}$ Relatedly, low-density development has negative impacts on watershed functions. Development in previously undeveloped areas "can dramatically change how water is transported and stored" as new construction creates "impervious surfaces and compacted soils that filter less water, which increases surface runoff and decreases ground water infiltration." Adequate permeable surfaces allow for groundwater supplies to be recharged through rain. ${ }^{104}$ Once a certain percentage of impervious cover is reached, however, "it is extremely difficult to maintain pre-development stream quality," 105 as stormwater that flows over pavement and parking lots picks up pollutants before discharging into nearby rivers or streams. ${ }^{106}$ The deterioration of water supplies affects human communities directly in terms of potable water sources, and indirectly as aquatic sources of food and revenue are harmed.

The consequences of low-density development for limited resources extend beyond water. Air quality is also impacted as trees are cut to make room for roads and development. Trees stabilize land, reduce siltation and erosion, produce oxygen, and sequester carbon dioxide. ${ }^{107}$ Loss of farmland to sprawl development raises a number of concerns about soil degradation and food scarcity, ${ }^{108}$ and pressures on available and desirable land may result in new projects being built on wetlands and floodplains, to the detriment of the resources' ability to cushion the blow of natural

\footnotetext{
102 Brian Clark Howard, "Worst Drought in 1,000 Years Predicted for American West," NATIONAL GEOGRAPHIC (Feb. 12, 2015), available at http://news.nationalgeographic.com/news/2015/02/150212-megadrought-southwest-waterclimate-environment/ (last visited Feb. 5, 2016).

103 United States Environmental Protection Agency, Office of Sustainable Communities Smart Growth Program, Protecting Water Resources with Higher-Density Development, 4 (January 2006), available at

http://www.epa.gov/sites/production/files/2014-03/documents/protect_water_higher_density1.pdf (last visited Feb. $5,2016)$.

104 American Rivers, "How Stormwater Affects Your Rivers," available at https://americanrivers.org/threatssolutions/clean-water/stormwater-runoff/ (last visited Feb. 5, 2016).

105 Daniel J. Hutch, "The Rationale for Including Disadvantaged Communities in the Smart Growth Metropolitan Framework,” 20 YALE L. \& POL’Y REV. 353, 360 (2002).

106 American Rivers, "How Stormwater Affects Your Rivers," available at https://americanrivers.org/threatssolutions/clean-water/stormwater-runoff/ (last visited Feb. 5, 2016).

107 William W. Buzbee, "Smart Growth Micro-Incentives and the Tree-Cut Tax Case," 17 GA. ST. U. L. REV. 999,1003 (2001).

108 See, e.g., Todd W. Daloz, Farm Preservation: A Vermont Land-Use Perspective, 12 VT. J. ENVTL. L. 427, 432-33 (2011); Tamara Mullen, The McMansion: Architecture's Role in Facilitating Urban Sprawl and Farmland Loss, 12 DRAKE J. AGRIC. L. 255, 265 (2007).
} 
disasters. ${ }^{109}$ The health of human communities depends on the ecosystem benefits that these resources provide. ${ }^{110}$ Low-density development spurred by self-driving cars is likely to contribute to further pressure on valuable resources, and have negative consequences for the human environment and the broader ecosystem.

\section{b. Biodiversity Losses}

Driverless cars may also pose a particular threat to biodiversity. Biodiversity refers to "the sum of the species, ecosystems, and genetic diversity of Earth[,]" 111 and is essential because the "number and type of plants and animals in an area determines the very structure and function of ecosystems across the planet." ${ }^{112}$ As driverless cars encourage construction of new homes and roads outside the city center, the biosphere faces the twin harms of habitat destruction and habitat fragmentation. ${ }^{113}$ Roads, tree cuts, and other aspects of suburban development both eliminate places for species to live and "destroy[ much of the ecological interconnectedness that is now believed essential to protecting or fostering biodiversity." 114

When roads bisect habitats, they divide large natural populations into smaller ones, ${ }^{115}$ and may cut off access to essential parts of a habitat, or phases of a migration. For instance, roads adjacent to lakes, rivers, and ponds can impede animals' access to water, and result in heightened

\footnotetext{
109 Patrick Gallagher, The Environmental, Social, and Cultural Impacts of Sprawl, NAT. RESOURCES \& ENV’T, Spring 2001, at 219, 221.

110 See, e.g., United Nations Environmental Program, "Ecosystems and Their Services," ECOSYSTEMS AND HUMAN WELL-BEING: A FRAMEWORK FOR ASSESSMENT, at 57, available at http://www.unep.org/maweb/documents/document.300.aspx.pdf (last visited Feb. 6, 2016).

${ }^{111}$ Lee Hannah, Thomas E. Lovejoy, and Stephen H. Schneider, "Biodiversity and Climate Change in Context," in Climate Change And Biodiversity 3 (Thomas E. Lovejoy and Lee Hannah, eds.) (Yale Univ. Press 2005).

112 EPA, "Our Built and Natural Environments: A Technical Review of the Interactions Among Land Use, Transportation, and Environmental Quality" 35, 2d ed. (2013).

113 See EPA, "Our Built and Natural Environments: A Technical Review of the Interactions Among Land Use, Transportation, and Environmental Quality” 34, 38-44, 2d ed. (2013);

Chen, Jim, “Across the Apocalypse on Horseback: Imperfect Legal Responses to Biodiversity Loss,” 17 WASH. U. J.L. \& POL'Y 13, 23 (2005) ("Among the drivers of biodiversity loss, habitat destruction is by far the deadliest."); see also Czech, Brian, "Chronological Frame of Reference for Ecological Integrity and Natural Conditions," 44 NAT. RESOURCES J. 1113, 1121 (2004) (“At the population level, habitat fragmentation is particularly problematic.”).

114 William W. Buzbee, "Smart Growth Micro-Incentives and the Tree-Cut Tax Case," 17 GA. ST. U. L. REV. 999 , $1002-$ 03 (2001).

115 Richard T.T. Forman, RoAd ECOlOGY: SCIENCE AND SOLUTIONS 4 (Island Press 2003).
} 
rates of mortality for species trying to cross these barriers. ${ }^{116}$ Species populations isolated by roads may also experience declines in genetic diversity that make them vulnerable to disease, changes in climate, and other impacts. ${ }^{117}$ The effects of roads extend beyond the road corridor itself, as roads create new "edge habitats" in their artificial clearings. ${ }^{118}$ These "edge habitats" have different physical and biological characteristics than the surrounding environment, and support different kinds of life. That means that they may be less hospitable to species already living in an ecosystem, and may serve as a corridor for invasive species better adapted to the road environment. In consequence, "[s]pecies that are sensitive to edge habitat, especially forest interior species, decrease in density and/or may be less likely to survive due to competition with exotic species, edge predators, and overall poor habitat quality." ${ }^{119}$ Perhaps inevitably, roads also lead to increased human access to previously undisturbed areas, ${ }^{120}$ followed by increased human activity, light, and noise that can have negative impacts on species survival. All of these changes often outpace the ability of the ecosystem to adapt. ${ }^{121}$ As a result, "[h]abitat destruction and degradation contribute to the endangerment of more than 85 percent of the species listed or formally proposed for listing under the federal Endangered Species Act.",122

\footnotetext{
${ }^{116}$ Jon P. Beckman \& Jodi A. Hilty, "Connecting Wildlife Populations in Fractured Landscapes," in SAFE PASSAGES: Highways, Wildlife, And Habitat Connectivity, Jon P. Beckman, Anthony P. Clevenger, Marcel P. Huijser, \& Jodi A. Hilty, eds. (Island Press 2010), at 8-9.

117 Jon P. Beckman \& Jodi A. Hilty, "Connecting Wildlife Populations in Fractured Landscapes," in SAFE PASSAGES: Highways, Wildlife, And Habitat Connectivity, Jon P. Beckman, Anthony P. Clevenger, Marcel P. Huijser, \& Jodi A. Hilty, eds. (Island Press 2010), at 13.

118 Sandra Zellmer, "Wilderness, Water, and Climate Change," 42 ENVTL. L. 313, 318 (2012) (noting "edge effects" of "erosion, poor water and air quality, noise, and invasive species").

119 Jon P. Beckman \& Jodi A. Hilty, "Connecting Wildlife Populations in Fractured Landscapes," in SAFE PASSAGES: Highways, Wildlife, And Habitat Connectivity, Jon P. Beckman, Anthony P. Clevenger, Marcel P. Huijser, \& Jodi A. Hilty, eds. (Island Press 2010), at 7.

${ }^{120}$ Jon P. Beckman \& Jodi A. Hilty, “Connecting Wildlife Populations in Fractured Landscapes," in SAFE PASSAGES: Highways, Wildlife, And Habitat ConneCtivity, Jon P. Beckman, Anthony P. Clevenger, Marcel P. Huijser, \& Jodi A. Hilty, eds. (Island Press 2010), at 5.

121 See Francesca Ortiz, "Biodiversity, the City, and Sprawl," 82 B.U. L. REV. 145, 150 (2002) (explaining that although ecosystems change, they change slowly and "accelerated losses to diversity can tax or collapse ecosystems before they have time to adapt.").

122 EPA, "Our Built and Natural Environments: A Technical Review of the Interactions Among Land Use, Transportation, and Environmental Quality” 35, 2nd ed. (2013).
} 
Picturing a map of the country in which driverless cars spur ever more remote development, along with roads to connect all of those homes or communities to one another, it soon becomes clear that this expansion pattern gradually eats away at the distance between where one development ends and the next begins. In this more holistic view, sprawl matters not just for the city it surrounds, but for its relationship to nearby developments as well. The expansion of development and roads due to driverless cars therefore has the potential to contribute to the national loss of biodiversity. Given the risk of this and other possible harms, we should endeavor to stave off the more negative aspects of driverless cars from the outset. To ensure a healthy future for ourselves and other species, we must protect the wider ecosystem in which we live, and preserve our natural resources and biodiversity. ${ }^{123}$ And to preserve our natural resources and biodiversity, we must care about density.

\section{Planning for Density}

Perhaps the simplest pair of rules that have been articulated regarding ecosystem preservation and management are: (1) "the bigger the better;" and (2) "the less intrusion the better." ${ }^{\prime 24}$ In other words, ecosystems are better off when humans take up less space. The development of open land presents a classic tragedy of the commons in which no individual actor internalizes the full social cost of his or her actions. This is particularly the case for driverless cars where, as noted, the impacts of development are not only the depletion of a common resource (land), but are also part of a cumulative impact on other public goods (open space, resources, and biodiversity). It is therefore incumbent on government actors to halt encroachment on habitat

\footnotetext{
${ }^{123}$ Cf. Jamison E. Colburn, "Localism's Ecology: Protecting and Restoring Habitat in the Suburban Nation,” 33 ECOL. L. Q. 945, 946-52 (2006) (noting importance of habitat protection for preservation of biodiversity, and suggesting solutions for the failings of current policy with regard to habitat protection in the urban and suburban ecosystem); United Nations Environmental Program, "Ecosystems and Their Services," Ecosystems AND HuMAN WELL-BEING: A FRAMEWORK FOR ASSESSMENT, at 49, available at http://www.unep.org/maweb/documents/document.300.aspx.pdf (last visited Feb. 6, 2016) (“[c]hanges in biodiversity can influence the supply of ecosystem services."). Theories regarding the ethical and moral underpinnings of an obligation to preserve natural resources vary widely. Gordon Steinhoff, Why We Should Protect Natural Areas, 5 Ariz. J. Envtl. L. \& Pol'y 364, 373-77 (2015).

124 Oliver Houck, “Are Humans Part of Ecosystems?,” 28 ENVTL. L. 1, 9 (1998).
} 
through planning for density. ${ }^{125}$ Planning for density is necessary because history has shown that it will not happen on its own. If the way we use our land is a reflection of our values, ${ }^{126}$ the United States has acted out a convincing devotion to cars. We as a country have a "perverse history of contorting our social patterns to accommodate the needs of the automobile." ${ }^{\prime 27}$ Unplanned development and unbridled enthusiasm for the potential of the open road have led to a nation where, even fifteen years ago, "20 percent of all land ... was within 417 feet of a road, and 50 percent was within a quarter-mile. Only about 18 percent of all land was more than 0.62 mile from a road, and about 3 percent was more than 3 miles." 128 Automobile-based planning has led to an unmistakable decline in human population density. ${ }^{129}$ In consequence, what open land there is that remains, and the other species that have managed to survive, are all the more precious. As the automobile transforms into a driverless vehicle unmoored from historic constraints, the prognosis for the ecosystem of the United States is grim if the automobile continues to dictate the national landscape.

Federal law requires designated metropolitan planning organizations ("MPOs”) to develop long-range transportation plans and transportation improvement programs to "promote the safe and efficient management, operation, and development of surface transportation systems" that will,

\footnotetext{
125 See, e.g., Richard L. Revesz, Foundations of Environmental Law and Policy 4, Oxford University Press (1997) (describing Garrett Hardin's classic essay on the tragedy of the commons and Hardin's call for "the use of the coercive powers of government to prevent excessive exploitation of a commons"). 126 See Timothy Beatley, Ethical Land Use: Principles of Policy and Planning 3, (Johns Hopkins Univ. Press 1994) (arguing that the "social allocation of land to different uses and activities is fundamentally and inextricably a problem of ethics.").

127 Paul Goldberger, "It Takes a Village," THE NEW YORKER 132 (March 27, 2000); James Kushner, THE POSTAutomobile City: Legal Mechanisms to Establish the Pedestrian-Friendly City 5, Carolina Academic Press (2004) ("Nowhere, other than in America, have nations and communities placed so much emphasis on accommodating the automobile and designing cities around the automobile."). "If you look at the twentieth century, the car has transformed society more than pretty much any other invention." "Google's X-Man: A Conversation with Sebastian Thrun,” Comments, 92 FOREIGN AFFAIRS 2, 4 (2013).

${ }^{128}$ EPA, "Our Built and Natural Environments: A Technical Review of the Interactions Among Land Use, Transportation, and Environmental Quality" 21, 2d ed. (2013).

129 See Edward H. Ziegler, "Sustainable Urban Development and the Next American Landscape: Some Thoughts on Transportation, Regionalism, and Urban Planning Law Reform in the 21 $1^{\text {st }}$ Century,"42 URB. LAW. 91, 95 (2011) (noting that despite an urban renaissance, population densities have declined, and without substantial reforms, metropolitan development will continue to perpetuate automobile dependence.).
} 
among other things, serve mobility and economic needs while considering resiliency, fuel consumption, and air pollution. ${ }^{130}$ Despite the possible impacts from the driverless car on these goals, however, a 2014 survey of MPOs in the nation's twenty-five largest metropolitan areas revealed that only one contained even a passing reference to autonomous vehicles in its most recent regional transportation plan. ${ }^{131}$ Many of the planners acknowledged the potentially transformative power of driverless cars, ${ }^{132}$ but felt that planning for driverless vehicle technology was difficult due to the unknown nature of the driverless future. ${ }^{133}$ As one planner remarked, “[w]e don't know what the hell to do about [incorporating autonomous vehicles into planning efforts at our MPO]. It's like pondering the imponderable." 134 Because even "too much hesitation over imponderables becomes its own sort of planning decision," 135 it is worth dedicating time to think through how best to begin the process of planning for the driverless future.

The discussion below suggests some ways in which governments at all levels might start that planning conversation. While not comprehensive, it suggests some ways to generate understanding of the possible impacts of these vehicles, and other tools that could be used to combat any negative consequences. For instance, current environmental review statutes might provide an explicit framework in which to discuss the impacts of driverless cars. State and local governments may be able to modify planning strategies already in place to develop a preemptive response to autonomous vehicle technology. And cities can take active measures to welcome driverless technology and draw

\footnotetext{
13023 U.S.C.A. \134(a)(1) (West 2016), amended by PL 114-94, Dec. 4, 2015, 129 Stat. 1312, Sec. 1201.

${ }^{131}$ Erick Guerra, Planning for Cars that Drive Themselves, JOURnAl OF PlANNING EDUCATION AND RESEARCH (2015), at 23.

132 Erick Guerra, Planning for Cars that Drive Themselves, JOURnAl OF PlANNING EDUCATION AND RESEARCH (2015), at 57 (noting examples of comments from planners that autonomous vehicles could, among other things, draw ridership away from public transit, create the potential for more unified public transit systems, increase the overall number of vehicle miles traveled, and encourage sprawl development).

133 Erick Guerra, Planning for Cars that Drive Themselves, JOURnAl OF PlanNING EDUCATION AND RESEARCH (2015), at 57.

134 Erick Guerra, Planning for Cars that Drive Themselves, JOURNAL OF PLANNING EDUCATION AND RESEARCH (2015), at 5.

135 Eric Jaffe, Why Aren't Urban Planners Ready for Driverless Cars?, The Atlantic's CityLab, available at http://www.citylab.com/cityfixer/2015/12/why-arent-urban-planners-ready-for-driverless-cars/419346 (last visited Dec. 19, 2015).
} 
on it to create denser communities. Discussion of the likely impacts of self-driving cars alongside decisions currently being made about the technology, combined with active measures to promote density at the suburban and urban level, may go a long way toward putting us back in the driver's seat when it comes to technology and land use.

\section{A. Planning for Environmental Impacts}

Federal and state statutes require consideration of the environmental impacts of certain government actions. This mandatory environmental review is likely the most direct means by which to assess the impacts of the driverless car. Namely, government involvement in driverless carrelated projects may subject those projects to the requirements of the National Environmental Policy Act ("NEPA") or state and local versions of NEPA. The passage of NEPA in 1969 introduced the idea of environmental impact review at the federal level, ${ }^{136}$ and inspired similar reviews at the state and local level. ${ }^{137}$ NEPA imposes no substantive requirements. Its power lies in its requirement that, for any proposed major federal action that has the potential to significantly impact the environment, federal agencies must prepare a detailed statement that addresses the "environmental impact of the proposed action, any adverse environmental effects, alternatives to the proposed action, and the relationship between local short-term uses of [the human] environment and the maintenance and enhancement of long-term productivity." 138 Those requirements allow NEPA to serve a crucial role in bolstering the dialogue regarding the expected impacts of government actions. ${ }^{139}$

\footnotetext{
136 See, e.g., Bradley C. Karkkainen, Toward a Smarter NEPA: Monitoring and Managing Government's Environmental Performance, 102 COLUM. L. REV. 903, 904 (2002).

137 See id. at 905, n.7 (noting that NEPA has "inspired dozens of 'little NEPAs' at the state and local levels," but also explaining that certain state statutes differ from the federal NEPA in that they include substantive provisions, while the federal NEPA is purely procedural.). 138 John R. Nolon, Protecting the Environment Through Land Use Law: Standing Ground 327, ELI Press (2015) (internal alterations omitted).

139 See, e.g., Richard J. Lazarus, The Making Of ENVIRONMENTAL LAW 85, Chicago: University of Chicago Press (2004) (describing role of NEPA in getting information to environmental advocates and agencies); Bradley C. Karkkainen, Toward A Smarter NEPA: Monitoring and Managing Government's Environmental Performance, 102 Colum. L. Rev. 903,910
} 
If a project is subject to NEPA, the government agency involved must prepare an analysis of environmental impacts ("environmental assessment," or "EA") ${ }^{140}$ that addresses the direct, indirect, and cumulative impacts of the federal action. ${ }^{141}$ As the federal government becomes increasingly involved in the driverless car sphere, there may be actions for which this kind of NEPA review is mandated. While it is beyond the scope of this Article to provide an extensive discussion of the ways in which NEPA may be implicated by driverless cars, two potential scenarios are outlined below. There may be other possibilities for this kind of review at the federal, state, and local levels. Regardless of the level at which such review occurs, it may play a critical role in providing government actors and other interested parties with information on the full environmental consequences of driverless cars as decisions about the technology are being made.

\section{FAST Act funds}

On December 4, 2015, President Obama signed into law the Fixing America’s Surface Transportation Act (“FAST Act” or “Act”), which authorizes federal surface transportation programs through 2020. ${ }^{142}$ The overall goal of the FAST Act is improvements to the U.S. "surface transportation infrastructure, including our roads, bridges, transit systems, and passenger rail network." ${ }^{143}$ The Act also contains some brief references to driverless cars. Notably, it set up a grant program for development of advanced transportation technologies, including "accelerat[ion

(2002) (describing information-forcing function of NEPA); Jonathan Poisner, A Civic Republican Perspective on the National Environmental Policy Act's Process for Citizen Participation, 26 Envtl. L. 53, 55 (1996) (noting that NEPA has "spawned the largest amount of citizen participation in environmental decision making over the last two decades.").

${ }^{140}$ Cf. Dep't of Transp. v. Pub. Citizen, 541 U.S. 752 (2004) (considering sufficiency of Environmental Assessment regarding Federal Motor Carrier Safety Administration's safety monitoring requirements for Mexican motor carriers without calling into question that an Environmental Assessment was warranted); cf. Cellular Phone Taskforce v. F.C.C., 205 F.3d 82, 94 (2d Cir. 2000) (upholding agency's lack of a formal Environmental Assessment under NEPA where its consideration of environmental impacts "functionally satisf[ied]" NEPA obligations).

14140 C.F.R. $\int 1508.25$.

142 United Stated Department of Transportation, “The Fixing America's Surface Transportation Act or 'FAST Act”" (last updated April 8, 2016) https://www.transportation.gov/fastact; H.R. 22, "Joint Explanatory Statement of the Committee of the Conference," available at http://transportation.house.gov/uploadedfiles/joint_explanatory_statement.pdf (last visited Jan. 8, 2016). 143 United States House of Representatives, Transportation \& Infrastructure Committee, "FAST Act: Info Packet," at 3, available at http://transportation.house.gov/fast-act/\#top (last visited Feb. 12, 2016). 
of] the deployment of . . . autonomous vehicles." 144 These grants can be made to "[s]tate or local government[s], transit agenc[ies], metropolitan planning organization[s] representing populations over 200,000, or other political subdivision[s] of a State or local government[, as well as to] research institutions." ${ }^{145}$ Eligible entities can use the funds to "deploy advanced transportation and congestion management technologies, ${ }^{, 146}$ including driverless cars. ${ }^{147}$ In short, Congress made available federal funds for which state and local governments can apply, and which can be used to, among other things, promote driverless car technology. ${ }^{148}$ While grants are currently available to no more than ten eligible entities, ${ }^{149}$ these funds have the potential to provide a helpful boost to selected communities hoping to integrate driverless car technology into their transportation plans. They could also provide a critical opportunity to ensure that the full environmental impacts of communities' plans for driverless cars are considered.

Receipt of federal funding can turn even exclusively state or local projects into "major federal actions" subject to the requirements of NEPA. In such a case, the determination of whether a given project is a major federal action will turn on the degree of federal funding for the project ${ }^{150}$ and the extent of federal oversight and involvement. ${ }^{151}$ The FAST Act allows for federal funding of

14423 U.S.C.A. S 503 (c)(4)(B)(viii) (West 2016).

${ }^{145}$ FAST Act, Sec. 6004, 23 U.S.C.A. \503(c)(4)(N)(i) (West 2016).

14623 U.S.C.A. \503(c)(4)(E) (West 2016). These technologies include “(i) . . traveler information systems; (ii) . . . transportation management technologies; (iii) infrastructure maintenance, monitoring, and condition assessment; (iv) ... . public transportation systems; (v) transportation system performance data collection, analysis, and dissemination systems; (vi) advanced safety systems, . . . (vii) integration of intelligent transportation systems with the Smart Grid and other energy distribution and charging systems; (viii) electronic pricing and payment systems; [and] (ix) advanced mobility and access technologies[.]" Id.

14723 U.S.C.A. \503(c)(4)(E)(vi) (West 2016).

148 See 23 U.S.C.A. $\int 503$ (c)(4)(E), (N)(i);

The FAST Act also makes available grants to regional university transportation centers to further objectives in autonomous vehicles, and calls for a GAO report on autonomous vehicle technology. FAST Act, Sec. 6016, 49 U.S.C. $\int$ 5505(c)(3)(E); FAST Act, Sec. 6025.

${ }^{149}$ FAST Act, Sec. 6004, 23 U.S.C. $\int 503(c)(4)(D)(i)$.

150 See Sierra Club v. U.S. Fish \& Wildlife Serv., 235 F. Supp. 2d 1109, 1120 (D. Or. 2002) (“There are no clear standards for defining the point at which federal participation transforms a state or local project into a major federal action. ... The matter is simply one of degree ....”) (internal citations omitted).

151 See, e.g., Envtl. Rights Coal., Inc. v. Austin, 780 F. Supp. 584, 601 (S.D. Ind. 1991) ("the receipt of federal funds by a state or private entity subjects that entity to restraint under NEPA only so long as the federal agency disbursing the funds retains a degree of influence over the project for which the funds are disbursed"). 
eligible projects up to $\$ 12$ million; ${ }^{152}$ grants may not constitute more than 50 percent of the cost of the project. ${ }^{153}$ Where "a project is only partially funded by the federal agency, federal courts have in some instances looked to the proportion of federal funding to non-federal funding to determine whether there is a major federal action." ${ }^{154}$ Thus, whether these grants are sufficient to transform the project into major federal action will likely depend on the overall size of the project and amount of funds granted. ${ }^{155}$

Government oversight may also convert a project into a major federal action. The FAST Act does not appear to contemplate direct federal involvement in projects following a grant, but the Secretary of Transportation does retain oversight over these projects. The Act requires that upon receipt of a grant, the entity must provide an annual report to the Secretary describing costs of the project compared to its benefits and savings, as well as how the project has met projected expectations. ${ }^{156}$ If, based on that report, the Secretary is not satisfied that the recipient is carrying out the grant requirements, the Secretary may cease further grant funding. ${ }^{157}$ That continued federal involvement in terms of funding for the project may be sufficient to transform a project into a major federal action subject to the reporting requirements of NEPA. ${ }^{158}$

15223 USCA \503 (c)(4)(J) (West 2016) (establishing that the Secretary may award grants to a minimum of five recipients per fiscal year and award those recipients no more than $\$ 60$ million for the duration of the project, amounting to a maximum of $\$ 12$ million per recipient).

${ }^{153}$ FAST Act, Sec. 6004, 23 U.S.C.A. \503(c)(4)(I)(i), (J), (K) (West 2016).

154 Sierra Club v. U.S. Dep't of Agriculture, 777 F. Supp. 2d 44, 61 (D.D.C. 2011).

155 See Sierra Club v. Fish \& Wildlife Serv., 235 F. Supp. 2d 1109, 1120-21 (discussing under what circumstances federal funding would transform the project into a "major federal action" and thereby trigger NEPA obligations).

15623 U.S.C.A. \503(c)(4)(F)(i) (West 2016). Specifically, the report must include "(I) data on how the project has helped reduce traffic crashes, congestion, costs, and other benefits of the deployed systems; (II) data on the effect of measuring and improving transportation system performance through the deployment of advanced technologies; (III) the effectiveness of providing real-time integrated traffic, transit, and multimodal transportation information to the public to make informed travel decisions; and (IV) lessons learned and recommendations for future deployment strategies to optimize transportation efficiency and multimodal system performance." 23 U.S.C.A. $\$ 503(\mathrm{c})(4)(\mathrm{F})(\mathrm{ii})$. 15723 U.S.C. $\$ 503(\mathrm{c})(4)(\mathrm{H})$.

${ }^{158}$ Envtl. Rights Coal., Inc. v. Austin, 780 F. Supp. 584, 595 (S.D. Ind. 1991) (describing the "minimum federal agency involvement that would permit federal court jurisdiction under NEPA" to include "situations in which the cessation of federal involvement would control the destiny of some aspect of the project"). 
If deemed a major federal action, the federal agency issuing the FAST Act funds would be required to satisfy NEPA by considering the direct, indirect, and cumulative impacts of the funding for the environment. Direct effects are those "caused by the action and [which] occur at the same time and place."159 There are unlikely to be any environmental impacts that could accurately be described as being directly caused by, and occurring at the same time and place, as the receipt of federal funds for implementation of a driverless car program. Indirect impacts of funding autonomous vehicle development, however, arguably include increased usage of autonomous vehicles. ${ }^{160}$ Assuming a sufficient causal connection between the funding and increased vehicles, ${ }^{161}$ the agency would have to consider the reasonably foreseeable indirect impacts on "population density ... and related effects on air and water and other natural systems, including ecosystems."162 As detailed above, these indirect consequences may be varied and substantial. Further, the Council on Environmental Quality's implementing regulations for NEPA require that agencies consider the "cumulative impacts" of their actions. ${ }^{163}$ A "cumulative impact" is an environmental impact "which results from the incremental impact of the action when added to other past, present, and reasonably foreseeable future actions regardless of what agency ... or

15940 C.F.R. \1508.8(a).

160 See, e.g., City of Davis v. Coleman, 521 F.2d 661, 675 (9th Cir. 1975) (noting that the growth-inducing effects of a highway project were "its raison d'etre," and the federal agency was required to consider the environmental impacts of that growth in an environmental impact statement (EIS)).

161 See, e.g., Dep't of Transp. v. Public Citizen, 541 U.S. 752 (2004). In Public Citizen, the Supreme Court considered the sufficiency of an EA prepared by the Federal Motor Carrier Safety Administration ("FMCSA") regarding its publication of safety monitoring requirements for Mexican motor carriers. Id. In that case, the "President [had] made clear his intention to lift [a] moratorium on Mexican motor carrier certification following the preparation of new regulations governing grants of operating authority to Mexican motor carriers." Id. at 760. Congress then enacted legislation dictating that no funds be spent to license Mexican trucks until the FMCSA promulgated those safety requirements. Id. Plaintiffs argued that FMCSA's EA regarding the safety requirements was deficient for its failure to consider the environmental impacts of increased truck traffic that would result once the guidelines were issued. Id. at 765 . The Court held, however, that there was an insufficient causal nexus between increased traffic and FMCSA's safety requirements to make make FMCSA "responsible under NEPA to consider the environmental effects" of that traffic. Id. at 768. In particular, the Court looked to the fact that FMCSA had no discretion to control the influx of trucks into the country, nor did it have the ability to refuse to issue the safety guidelines. Id. Based on those factors, the Court found no "reasonably close causal relationship" between the environmental effect and the alleged cause that NEPA requires. Id. at 767-68.

16240 C.F.R. $\int 1508.8$.

163 See 40 C.F.R. S 1508.25 (“[A]gencies shall consider . . cumulative effects” in their environmental impact statements.). 
person undertakes such other actions. Cumulative impacts can result from individually minor but collectively significant actions taking place over a period of time." ${ }^{164}$ A cumulative impacts analysis could provide for consideration of driverless cars' impacts in light of species population in a particular area, ${ }^{165}$ habitat destruction, ${ }^{166}$ and other land use issues, including air pollution, public health, and sprawl development. ${ }^{167}$ This piece of the analysis may be important for forcing consideration of the consequence of each smaller increases in driverless cars, such as may be attributable to federal funding, when combined with a more widespread adoption of the technology. In this way, an EA for projects funded by the FAST Act could provide a means of seeing a comprehensive picture of how federal funding for driverless cars may impact the environment.

\section{NHTSA Safety Standards}

As noted, the Department of Transportation's National Highway Traffic Safety

Administration (NHTSA) has also announced its intention to promulgate "best-practice guidance to industry on establishing principles of safe operation for fully autonomous vehicles." 168 This guidance is just one of a set of milestones that NHTSA has committed to for 2016. Its other intended actions include: working to develop a model state policy on automated vehicles; responses to requests for interpretation by manufacturers; proposed use of NHTSA's exemption authority as needed for development of driverless technology; and development of new tools as needed to

\footnotetext{
164 Id.

165 See, e.g., Sierra Club v. U.S. Fish \& Wildlife Serv., 235 F. Supp. 2d 1109, 1130-32 (D. Or. 2002) (demonstrating how a cumulative impact analysis related to species population could be applied in courts).

166 See, e.g., Habitat Educ. Ctr., Inc. v. Bosworth, 363 F. Supp. 2d 1090, 1102 (E.D. Wis. 2005) (discussing the application of a cumulative impact analysis in the context of a logging and deforestation project).

167 See, e.g., W. N. Carolina All. v. N. Carolina Dep't of Transp., 312 F. Supp. 2d 765, 770-73 (E.D.N.C. 2003)(listing the impacts that plaintiffs alleged should have been included in the government's EA as part of its cumulative impacts analysis related to other projects along the I-26 corridor, and finding that the government was required to consider these cumulative impacts of other projects).

168 "DOT/NHTSA Policy Statement Concerning Automated Vehicles: 2016 Update to 'Preliminary Statement of Policy Concerning Automated Vehicles," available at http:/ www.nhtsa.gov/staticfiles/rulemaking/pdf/AutonomousVehicles-Policy-Update-2016.pdf (last visited Feb. 15, 2016).
} 
respond to autonomous vehicles. ${ }^{169}$ To the extent that any of these actions, or further regulatory measures, ${ }^{170}$ have legal significance, ${ }^{171}$ they may constitute a major federal action for purposes of NEPA. Creation of an EA for these guidelines would provide an opportunity for the impacts of regulation of and guidelines for driverless cars to be considered and discussed in a public forum.

A number of states and localities also have NEPA-like planning statutes that may provide triggers for environmental analyses. To the extent that actions that implicate driverless cars are taken on the state and local levels, any required "baby NEPAs" can also help to ensure that the environmental impacts of decisions regarding driverless cars are considered. Again, although these statutes do not require any particular action on the part of planners, ${ }^{172}$ they can play an important role in generating discussion and awareness of the kinds of impacts that may accompany widespread introduction of these vehicles. ${ }^{173}$ Preparation of these kinds of analyses may help to clarify the connection between driverless cars and development, and make clear the task that planners have at hand in avoiding negative outcomes.

\section{B. Practical Steps}

\footnotetext{
${ }^{169}$ Press Release, “Secretary Foxx unveils President Obama’s FY17 budget proposal of nearly \$4 billion for automated vehicles and announces DOT initiatives to accelerate vehicle safety innovations," Jan. 14, 2016, http://www.nhtsa.gov/About+NHTSA/Press+Releases/dot-initiatives-accelerating-vehicle-safety-innovations01142016.

170 See, e.g., David Shepardson \& Bernie Woodall, "Tesla crash raises concerns about autonomous vehicle regulation," Reuters (July 1, 2016) http://www.reuters.com/article/us-tesla-autopilot-idUSKCN0ZH4VO (quoting former NHTSA chief Joan Claybrook as calling for the agency "to set performance standards for electronic systems like Autopilot[,]" because the world of autonomous vehicles is like the "Wild West. The regulatory system is not being used[.]"). 171 See, e.g., Columbia Riverkeeper v. U.S. Coast Guard, 761 F.3d 1084, 1095 (9th Cir. 2014) (noting that courts have found legal significance where an agency decision "determine[s] rights or obligations from which legal consequences will flow[,]" and that as a result, a court has concluded that "an agency's incidental take statement was the functional equivalent of a permit and therefore ... trigger[ed] NEPA obligations.”); see also Ramsey v. Kantor, 96 F.3d 434, 444 (9th Cir. 1996).

172 W. N. Carolina All. v. N. Carolina Dep’t of Transp., 312 F. Supp. 2d 765, 769 (E.D.N.C. 2003) (“NEPA does not mandate a particular substantive outcome.").

173 See, e.g., Richard J. Lazarus, The Making OF Environmental LAw 85, Chicago: University of Chicago Press (2004) ("NEPA's mandate that agencies disclose the environmental impacts of their actions [has] resulted in substantial changes in agency behavior with positive effects on environmental protection."); James Rasband, et al., NATURAL RESOURCES LAW AND POLICY 282-83, Foundation Press (2004) (noting that NEPA has "achieved a great deal" in terms of providing information on agency actions to the public, putting pressure on agencies to adopt environmental values, and causing agencies to mitigate adverse impacts).
} 
These discussions of the impacts of driverless cars may be important for their ability to provide a comprehensive look at potential environmental impacts, should the federal or state government decide to take actions regarding these vehicles. There are also steps that can be taken to more proactively plan for and promote density as the technology becomes more widespread. At the state, regional, or local level, policymakers can focus on ensuring that the master plans that govern zoning and other decisions are updated to eliminate practices that foster low-density development, with a particular mind to the expected impacts of driverless cars. Further, the utility of some traditional land use planning measures already being employed may be altered by this new technology. Planners should consider discontinuing those practices likely to contribute to sprawl in the wake of driverless cars, and adopting any new tools that may help to incentivize denser development.

It is not sufficient to be anti-sprawl, however; successful curbing of the human footprint will also require work to create better, more appealing dense developments. To that end, cities can work to promote density in the face of driverless cars by working to promote a smooth transition to the technology. Widespread adoption of driverless vehicles in cities may help, in and of itself, to

promote the density-reinforcing aspects of the technology, including access to hard-to-reach parts of the city and shared vehicle fleets. Thus, cities should plan ahead for how best to incorporate this technology into their infrastructure without undermining public transportation, a traditional strength of the city, or pushing development outward. By combining efforts to both contain sprawl and improve density, government actors at all levels may be able to harness the beneficial aspects of driverless technology while avoiding some of the harms.

\section{State and Local Plans}

Given the potential for driverless cars to undo progress toward density made in the past several decades, planning for this new technology is critical in non-urban areas. States, which have 
the ability to play a role in defining the rules for driverless cars within their borders, should use that opportunity to integrate driverless cars into existing state comprehensive planning for roads and the environment, and should require the same kind of planning from local governments. Responsible government bodies in suburban areas should integrate knowledge about driverless cars into tested anti-sprawl theories to evaluate what makes sense for their community. Similarly, federallymandated MPOs should act on their mandate to "protect and enhance the environment, promote energy conservation, improve the quality of life, and promote consistency between transportation improvements and State and local planned growth and economic development patterns" ${ }^{\prime 174}$ by moving forward on analyses of the likely impacts of driverless cars, and the possible solutions. The discussion below highlights some of the ways in which responsible parties might be able to adjust established planning techniques for the arrival of driverless cars.

\section{a. Enabling Acts and Master Plans}

The primary responsibility for regulation of driverless cars is likely to fall to the states. ${ }^{175}$ This responsibility may also give rise to a planning opportunity, as localities derive their planning and zoning authority from the state. ${ }^{176}$ All states have adopted the Standard Zoning Enabling Act of 1926 in one form or another, ${ }^{177}$ which requires that zoning be conducted "in accordance with a comprehensive plan." ${ }^{178}$ Although this mandate has not been consistently interpreted or enforced, ${ }^{179}$ the complementary Standard City Planning Enabling Act gives "cities the power to

17449 U.S.C.A. $\$ 5304$ (d)(1)(E) (West 2016) as amended by the FAST Act, PL 114-94.

${ }^{175}$ Cf. Bryant Walker Smith, Automated Vebicles Are Probably Legal in the United States, 1 TEX. A\&M L. REv. 411, 500-08 (2014) (describing state legislation on driverless cars).

176 See. e.g., Rapoport v. Zoning Bd. of Appeals of City of Stamford, 19 A.3d 622, 635 (Conn. 2011).

177 Although adopted versions of the Act vary among the states, "the similarities remain greater than the differences, and the Standard Act remains the most practical point of departure in the examination of state zoning enabling statutes." 1 Am. Law. Zoning \2:11 (5th ed.).

${ }^{178}$ United States Department of Commerce, A Standard State Zoning Enabling Act $₫ 3$ (rev. ed. 1926); Edward J. Sullivan \& Matthew J. Michel, Ramapo Plus Thirty: The Changing Role of the Plan in Land Use Regulation, 35 URB. LAw. 75, 7576 (2003).

179 See, e.g., Edward J. Sullivan \& Matthew J. Michel, Ramapo Plus Thirty: The Changing Role of the Plan in Land Use Regulation, 35 URB. LAW. 75, 75-76 (2003). 
develop a master plan, including a 'zoning plan."'180 Further, "the statutes of every state provide for preparation of the master plan by the planning board or planning commission." ${ }^{181}$ Generally speaking, master plans are "long-term blueprint[s] used as a guiding and predictive force in the physical development of a community.", 182 They are not themselves legally binding, but are "guide[s] to community development ... that may be implemented through zoning." 183

State enabling acts may dictate required elements of a master plan, including "land use, population density, environmental quality," and other factors. ${ }^{184}$ Thus, as states pass new laws regarding driverless cars, state legislatures could amend their enabling act to require explicit consideration of impacts on population density and the environment from adoption of this new technology at a local and regional level. Such a requirement could help to ensure that driverless cars are adopted only with full consideration of their possible impacts. Master plans can be implemented through zoning, statutes, ordinances or regulations that elevate them to a "true regulatory device" enforceable in court. ${ }^{185}$ Even without such binding obligations, however, there is value in ensuring that local planning authorities will be forced to consider the shape of their communities after adoption of self-driving cars. Establishing a rationale for density promotion in a comprehensive plan may also provide a legal basis for local planning efforts. ${ }^{186}$ In making needed alterations to their master, or comprehensive, plans, localities should consider the aforementioned possible consequences of self-driving cars for their communities, and set planning goals accordingly.

\section{b. Land Use Planning Measures}

\footnotetext{
180 Roderick M. Hills, Jr. \& David Schleicher, Planning an Affordable City, 101 IOwA L. REV. 91, 98 (2015).

1813 Rathkopf's The Law of Zoning and Planning \ 47:2 (4th ed.).

18283 Am. Jur. 2d Zoning and Planning $\int 18$.

18383 Am. Jur. 2d Zoning and Planning $\int 18$.

1843 Rathkopf's The Law of Zoning and Planning $\int 47: 2$ (4th ed.).

185 See Pringle v. Montgomery Cty. Planning Bd. M-NCPPC, 69 A.3d 528, 534 (Md. 2013).

186 See John R. Nolon, Protecting The Environment Through Land Use Law: Standing Ground 63, ENVIRONMENTAL LAW INSTITUTE (2014) (“Communities that wish to adopt aggressive environmental protections are well advised to put the rationale for such regulations in their comprehensive plans.")
} 
Whether part of a comprehensive plan or not, states and localities have a wide array of tools available to them to promote density. These land use planning measures, including zoning for dense development, implementation of growth boundaries, elimination of parking requirements, transitoriented development, and others have been discussed at length elsewhere, ${ }^{187}$ and a review of these more traditional anti-sprawl measures is beyond the scope of this Article. It is worthwhile, however, for communities either planning for or already engaged in these kinds of initiatives to consider how self-driving cars may impact those efforts. To the extent that planning measures are already being employed by a locality, community leaders may be able to build on momentum surrounding dense development to implement coordinated planning decisions regarding driverless cars. And even for cities that have not historically embraced such land use controls, driverless cars may offer new incentives to do so. For instance, growth boundaries or conservation easements, while often controversial, may become more compelling where the time-cost of travel no longer serves as a constraint on sprawl. Pushback from community members regarding elimination of parking requirements may also be alleviated in the face of self-driving cars that can be used in shared fleets, or drive themselves elsewhere to park. The radical possibilities presented by this new technology warrant a comprehensive reevaluation of planning techniques.

\section{Preparation for the Driverless City}

\footnotetext{
${ }^{187}$ For a representative discussion of these kinds of measures, see, e.g., Patricia E. Salkin, From Euclid to Growing Smart: The Transformation of the American Local Land Use Ethic into Local Land Use and Environmental Controls, 20 PACE ENVTL. L. REV. 109, 118-19 (2002) ("To implement these smart growth environmental goals, advocates urge local governments to use a variety of traditional local land use controls such as: transfer of development rights; purchase of development rights and other market mechanisms that can preserve land; coordinate and link local, state, and federal planning on land conservation and development; innovative financing tools to facilitate open space acquisition and preservation (e.g., local property tax incentives); regional development strategies that better protect and preserve open space in edge areas; local green infrastructure plans; designated networks of trails and greenways; cluster development and incentive zoning to preserve open space; promoting agricultural districts as a mechanism to keep private working lands; and partnering with local land trusts and conservancies to acquire and protect open lands (e.g., through conservation easements).") For more concrete planning suggestions, see generally, e.g., SMART GROWTH ZONING CODES: A RESOURCE GUIDE, Local Government Commission (2004); Avi Friedman, PlanNING THE NeW SubURBIA: FleXIBILITY BY DeSIGN, Vancouver: UBC Press (2002).
} 
People need to live somewhere; thus, to preserve open space, "we must save our cities." 188

As such, one of the best ways to combat sprawl may be to focus on making cities livable, and to ensure that cities position themselves to provide a workable alternative to sprawl. Driverless cars are both able to facilitate that effort, and are dependent on such density-promotion if the vision of the technology as a means of reducing our dependency on personal automobiles is to take hold. ${ }^{189}$ There are specific ways in which cities could respond to driverless car that may make them more vibrant places to live, with greater opportunities for density, while at the same time promoting the new transportation technology. Although the future of driverless cars may be unknown, the discussion below attempts to outline some actions that will be useful for cities regardless of the shape of the technology's future and the length of its timeline.

\section{a. Develop authorization measures on the forefront of regulation}

Whether and where autonomous vehicles will be permitted to drive is currently an open question. Five states and the District of Columbia have enacted bills regarding autonomous vehicles, ${ }^{190}$ and regulatory agencies in two states and the District of Columbia have issued or are in the process of issuing regulations related to autonomous driving. ${ }^{191}$ A number of other states have

\footnotetext{
188 David Rusk, Inside Game/Outside Game: Winning StrategIES FOr SAVIng Urban AmeriCa 196 (Brookings Institution Press 1999) (quoting Jack Laurie, president of the Michigan Farm Bureau); see also United States Environmental Protection Agency, "Our Built and Natural Environments: A Technical Review of the Interactions Among Land Use, Transportation, and Environmental Quality," 2d ed., 31 (2013) (noting that "[w]here and how we build new housing and infrastructure needed to accommodate projected population growth will have important environmental impacts.”).

189 See David Schleicher, "How Land Use Law Impedes Transportation Initiatives," Yale Law School, Public Law Research Paper No. 565 (2016), available at http://papers.ssrn.com/sol3/papers.cfm?abstract_id=2763696\#\# ("While self-driving cars will permit greater . . . densities, they also need such densities to be useful [in a car-sharing framework]. If such density is not permitted [or present], there will be little incentive to build cars to fit that use. That is, land use laws will partially drive technological development.").

190 California (SB 1298); District of Columbia (B19-0931); Florida (CS/HB1207, SB 52); Michigan (SB 0169, SB 0663); Nevada (AB 511, SB 140, SB 313); Tennessee (HB 616, SB 598).

191 See California Dept. of Motor Vehicles, Deployment of Autonomous Vehicles for Public Operation (draft deployment regulations issued Dec. 16, 2015), available at

https://www.dmv.ca.gov/portal/dmv/detail/vr/autonomous/auto (last visited Jan. 5, 2016); District of Columbia Department of Motor Vehicles, available at dcclims1.dccouncil.us/images/00001/20130110191554.pdf; Nevada Department of Motor Vehicles (R084-11).
} 
proposed similar kinds of legislation. ${ }^{192}$ In 2013, NHTSA issued a preliminary statement of policy regarding autonomous vehicles in which it outlined five levels of automation for personal vehicles, and discussed its own past and future research plans. ${ }^{193}$ The NHTSA statement also noted that "states are well suited to address issues such as licensing, driver training, and conditions for operation related to specific types of vehicles," but recommended that states permit operation of self-driving vehicles only for testing. ${ }^{194}$ As noted, in January 2016 the NHTSA announced its intention to conduct a rulemaking regarding safety standards for testing vehicles within the next six months.

There also appears to be fairly widespread acceptance among scholars in this new area that driverless cars are already "probably legal" in the absence of state action. The longstanding common law principle that anything not prohibited is permitted, and driverless cars' arguable compliance with the three principle applicable legal regimes— the 1949 Geneva Convention on Road Traffic, National Highway Traffic Safety Administration regulations, and the vehicle codes of all 50 states-may mean that states need not take any further action to legalize self-driving vehicles. ${ }^{195}$ The strength of this argument has yet to be tested on a widespread basis, and may ultimately depend on whether lawmakers and courts accept the argument that the "driving" done by self-driving cars

\footnotetext{
${ }^{192}$ For a current list of such measures, see Gabriel Weiner and Bryant Walker Smith, Automated Driving: Legislative and Regulatory Action, cyberlaw.stanford.edu/wiki/index.php/Automated_Driving:_Legislative_and_Regulatory_Action (last visited Jan. 5, 2016).

${ }^{193}$ National Highway Traffic Safety Administration, Preliminary Statement of Policy Concerning Automated Vehicles 49, available at

http://www.nhtsa.gov/About+NHTSA/Press+Releases/U.S.+Department+of+Transportation+Releases +Policy+on +Automated+Vehicle+Development (last visited Jan. 5, 2016).

${ }^{194}$ National Highway Traffic Safety Administration, Preliminary Statement of Policy Concerning Automated Vehicles 10 , available at http://www.nhtsa.gov/About+NHTSA/Press+Releases/U.S.+Department+of+Transportation+Releases+Policy+on +Automated+Vehicle+Development (last visited Jan. 5, 2016).

195 Bryant Walker Smith, "Automated Vehicles are Probably Legal in the United States," 1 TEX. A\&M L. REV. 411, 41213 (2014); see also, e.g., Spencer Peck, Leili Fatehi, Frank Douma, \& Adeel Lari, "The SDVs are Coming! An Examination of Minnesota Laws in Preparation for Self-Driving Vehicles,” 16 MINN. J. L. SCI. \& TECH. 843, 867-76 (2015).
} 
complies with regulations already in place for human operation of vehicles. ${ }^{196}$ Assuming that driverless cars are legal without state approval, ${ }^{197}$ municipalities may take action to regulate the operation of driverless cars within their bounds. ${ }^{198}$ City regulations regarding the operation of driverless cars could foster a sense of security for companies interested in bringing cars into a marketplace, and could potentially prompt state legislatures to institute their own regulatory measures on the subject. Local governments in search of model language for their regulations could look to the variety of strategies already selected at the state level, ${ }^{199}$ or look to language proposed by scholars. $^{200}$

There is a strong possibility that municipal regulations regarding driverless cars would be preempted by any state or federal regulations that follow. ${ }^{201}$ This may give pause to local governments who fear that time invested in planning and promulgating regulations, and money allocated to any necessary infrastructure, will be wasted on measures that are ultimately overturned.

196 See Spencer Peck, Leili Fatehi, Frank Douma, \& Adeel Lari, The SDV s are Coming! An Examination of Minnesota Laws in Preparation for Self-Driving Vehicles," 16 MINN. J. L. SCI. \& TECH. 843, 855 (2015) (describing what it means to "drive" a vehicle). A recent federal statement supports this analysis. See Alex Davies, "Feds Say They'll Count Computers as Human Drivers," WiRED (Feb. 10, 2016), available at http://www.wired.com/2016/02/feds-say-theyll-count-computersas-human-drivers/ (last visited Feb. 15, 2016).

197 At least one state has accepted this analysis. See Letter to Warren V. Ganjehsani, Esq., General Counsel, South Carolina Department of Public Safety from Anne Marie Crosswell, Assistant Attorney General, Office of the Attorney General, State of South Carolina (Aug. 6, 2015), 2015 WL 4977735 (S.C.A.G.), at* 3 (noting that, in the absence of action by the South Carolina state legislature on a pending bill regarding driverless cars, testing of autonomous vehicles on the roadways of South Carolina was "permissible so long as the various requirements imposed on drivers and motor vehicles operating on our State's highways were complied with").

198 Cf. Wilton v. Henkin, 52 Cal. App. 2d 368, 372, 126 P.2d. 425, 428 (1942) ("Until the state acts . . . the field remains subject to municipal regulation, and the State Legislature has no power to forbid the municipality to so act."); see also "Conflict between statutes and local regulations as to automobiles," 147 A.L.R. 522.

${ }^{199}$ For a current list of state action on driverless car legislation, see Gabriel Weiner and Bryant Walker Smith, Automated Driving: Legislative and Regulatory Action, cyberlaw.stanford.edu/wiki/index.php/Automated_Driving:_Legislative_and_Regulatory_Action (last visited Feb. 6, 2016).

${ }^{200}$ For a draft bill proposed by a legal scholar, see Bryant Walker Smith, "Automated Vehicles are Probably Legal in the United States," 1 TEX. A\&M L. REV. 411, 508-16 (2014).

201 See generally "Conflict between statutes and local regulations as to automobiles," 147 A.L.R. 522. "[]t is well settled as a general rule that municipalities, having the power to regulate the use of their streets, may enact valid rules and regulations for the government of motor vehicles within their precincts, so long as they are not in conflict with or repugnant to legislative enactments governing the use of such vehicles; but that such ordinances are invalid if they are in conflict with statutes relating to the subject." Id. at (I). 
Driverless car companies, however, may be wary of operating in a regulatory void. ${ }^{202}$ The lack of action at the state and federal level provides local governments with an opportunity to attract driverless cars to their areas by providing clear operational frameworks. And even if ultimately preempted, work by municipalities in this area may be worthwhile if it serves as a catalyst for improved clarity, and helps to position a city on the leading edge of this technology.

\section{b. Create framework for density-promoting uses of driverless cars}

In the survey of MPOs discussed above, one of the concerns expressed by planners was an inability to know whether and when self-driving automobile technology would become widespread. For that reason, local governments may be reluctant to provide a full regulatory framework for driverless cars, or to commit resources dedicated solely to this technology. But cities could take certain density-promoting actions that would be beneficial even in the interim or absence of driverless vehicles. A focus on these kinds of strategies would allow for planning for driverless cars without fear of wasting resources should the technology fail to materialize in expected ways or within the expected timeframe.

\section{Modified parking requirements}

Driverless cars are expected to have the ability to drive themselves to remote parking sites when not in use. That ability opens up the opportunity to do away with automobile parking in its current form. Even beyond self-driving cars, there are reasons to look for ways to reduce available parking in cities. For many cities, ${ }^{203}$ minimum parking requirements lead to large amounts of unused urban space. ${ }^{204}$ With sufficient saturation of the automobile market by driverless cars, cities could

\footnotetext{
202 Cf. Brian Fung, "Google's driverless cars are now legally the same as a human driver," The Washington Post (Feb. 10, 2016), https://www.washingtonpost.com/news/the-switch/wp/2016/02/10/googles-driverless-cars-are-now-legallythe-same-as-a-human-driver/ (describing letter sent by Google to NHTSA requesting clarification on the definition of "driver" under federal law).

${ }^{203}$ Cities vary in the amount of parking available in their central business districts. But " $[\mathrm{h}]$ igher density leads to a higher quality of life only in cities that restrict rather than require off-street parking," such as San Francisco and New York City. See Donald Shoup, The High Cost of Free PArking 162-65, American Planning Association (2011).

${ }^{204} \mathrm{Id}$. at 111 (summarizing studies that show that parking requirements create underused parking lots in cities).
} 
eliminate much of the parking that occupies urban areas in the form of reserved street spaces and parking garages. This could present new planning opportunities for affordable housing and other amenities. ${ }^{205}$ Given the scarcity of urban land, the reopening of large swaths of space to nonautomobile uses holds great promise. Planners can identify now the neighborhoods most impacted by parking requirements, and can work to reduce parking requirements and availability even before the driverless car arrives in the streets. Charging market rates for parking and eliminating minimum parking requirements could go a long way toward encouraging density.

Importantly, driverless cars are still cars, and will still need garages, charging stations and other infrastructure. As seen in the early assumption that horse barns could sufficiently provide for the needs of the automobile, new technologies may require new approaches to space and storage. Cities should plan now for how those needs for driverless cars might best be met, keeping in mind space requirements and potential congestion issues. To facilitate that process, traffic studies and other preliminary steps can be taken to identify possible locations for this infrastructure, and the necessary environmental studies can be conducted to determine the impacts of various siting options.

\section{Fleet abilities}

Many envision the future of driverless cars as involving shared fleets of vehicles. ${ }^{206}$ Allowing these kinds of fleets to operate in either public or private form could harness many of the potential benefits of self-driving vehicles, including the density-promoting function of having a ready source of urban transit. ${ }^{207} \mathrm{~A}$ number of municipalities are currently working to establish new rules for ride sharing services like Uber and Lyft that have gained enormous popularity in the last couple of

\footnotetext{
205 Adeel Lari, Frank Douma \& Ify Onyiah, "Self-Driving Vehicles and Policy Implications: Current Status of Autonomous Vehicle Development and Minnesota Policy Implications," 16 MiNN. J.L. SCI. \& TECH. 735, 758 (2015). 206 Mike Isaac, “G.M., Expecting Rapid Change, Invests \$500 Million in Lyft,” Technology, THE NeW YORK Times (Jan. 4, 2016), available at http:/ / www.nytimes.com/2016/01/05/technology/gm-invests-in-lyft.html?ref=technology (last visited Jan. 4, 2016).

207 See infra at Section III(C).
} 
years. ${ }^{208}$ As policymakers hash out the details of these new regulations, they should also consider how driverless cars may fit into this framework, and address needed gaps in the law accordingly. For instance, much of the debate to date has been about how background check requirements and other regulations applicable to drivers for taxi companies apply to newer transportation companies. $^{209}$ Along with any changes to those rules, local governments should include in any new laws a provision that makes clear which requirements apply only to cars with human drivers. They could also take the opportunity to reassess all of the rules regarding shared vehicle services, and consider adding in different liability and insurance rules as needed for driverless fleets. Such clarifications in advance of self-driving technology may encourage its more widespread adoption, as the "lack of an effective legal framework can be the main obstacle to innovation and economic growth[.]"210

Thus, putting in place a partial regulatory framework could facilitate the eventual adoption of driverless fleets once the technology comes of age. It also presents an early opportunity for cities to better prepare the necessary regulatory framework and consider plans for how to help taxi drivers and others whose livelihood may be eliminated by driverless vehicles transition to a new economy. ${ }^{211}$ As seen in current conflicts between ride-sharing companies and the taxi cab industry, plans for driverless car fleets are likely to face significant opposition from driver-based modes of transit.

\footnotetext{
208 Douglas MacMillan, “Uber Laws: A Primer on Ridesharing Regulations,” THE WALL STREeT JOURNAL (Jan. 29, 2015), available at http://blogs.wsj.com/digits/2015/01/29/uber-laws-a-primer-on-ridesharing-regulations/ (last visited Jan. 19, 2016).

209 See, e.g., Luz Lazo, "D.C. taxi drivers sue D.C. over Uber legislation,” THE WASHINGTON Post (May 22, 2015), available at https://www.washingtonpost.com/news/dr-gridlock/wp/2015/05/22/d-c-taxi-drivers-sue-d-c-over-uberlegislation/ (noting that "D.C. cabdrivers and taxi companies have criticized [D.C.] legislation [legalizing Uber and other shared car services] as unfair because they say the drivers for uberX, Lyft and Sidecar don't have to meet the same licensing requirements, regulations, restrictions and costs as regular cabdrivers.").

${ }^{210}$ Sofia Ranchordás, Does Sharing Mean Caring? Regulating Innovation in the Sharing Economy, 16 MINN. J.L. SCI. \& TECH. 413, 444 (2015).

${ }^{211}$ Cf. Brishen Rogers, The Social Costs of Uber, U. CHI. L. REV. Dialogue 85, 101-02 (2015) (discussing Uber's impacts possible impacts on low-wage employees).
} 
Planning for the possible loss of employment for hundreds of people will be a crucial step toward adoption of driverless cars for any city.

\section{Use congestion pricing to deter long commutes}

Cities should also consider the implementation of congestion pricing to deter a driverless car-fueled migration from city to suburb. To date, time sitting in traffic has ensured that at least some of those costs are felt by most commuters. But if self-driving cars reduce the time-cost of commuting, even that system check will be eliminated. Congestion pricing for a driverless vehicle could force commuters to internalize at least some of the costs of sprawl, and reinforce the importance of public transit, as described below.

In simple terms, congestion pricing refers to charging road users a fee for use of the road at certain times of day in which usage is high, as a correction of the policy that generally sets the price of road space at zero. ${ }^{212}$ This fee forces drivers to internalize the costs of their decision to drive. ${ }^{213}$ The costs reflected in congestion pricing may include time costs, external congestion costs, and other costs such as environmental or governmental. ${ }^{214}$ In general, congestion pricing is implemented in one of three ways: "facility pricing, which charges fees for use of a bridge, tunnel, or small segment of road;" "road pricing, which assesses a fee along a specific roadway;" or "cordon pricing, which establishes a series of congestion toll collection stations in a ring around a congestion area" and for which "[c]ommuters are charged a fee as they enter the area." 215

Use of any of these systems can mean that the consequences of living on one side of the pricing divide versus another are quite costly, making decisions about how and where to institute

\footnotetext{
${ }^{212}$ Gabriel Weil, Subnational Climate Mitigation Policy: A Framework for Analysis, 23 COLO. J. INT'L ENVTL. L. \& POL’Y 285 , 303-05 (2012).

${ }^{213}$ Jonathan Remy Nash, Economic Efficiency Versus Public Choice: The Case of Property Rights in Road Traffic Management, 49 B.C. L. REV. 673, 725 (2008).

214 Michael H. Schuitema, Road Pricing As A Solution to the Harms of Traffic Congestion, 34 TrANSP. L.J. 81, 93 (2007).

215 Michael H. Schuitema, Road Pricing As A Solution to the Harms of Traffic Congestion, 34 Transp. L.J. 81, 93-94 (2007).
} 
congestion charges often controversial. ${ }^{216}$ The technological and information transmission

capabilities of driverless cars, however, should enable sophisticated pricing that would avoid the kind of line-drawing that often concerns businesses and residents and would better address sprawl concerns. For instance, municipalities could institute a charge per mile based on daily vehicle miles traveled before passing a certain checkpoint. If calculated appropriately, these kinds of charges could provide market incentives toward denser development. ${ }^{217}$

One major critique of congestion pricing is that it may operate as a regressive tax. ${ }^{218}$ Some commentators have suggested possibilities for addressing that concern through forms of creditbased congestion pricing, where revenue generated through congestion pricing is redistributed to all drivers. Under such a system, "frequent long-distance peak-period drivers subsidize others, in effect paying them to stay off congested roads." 219 That kind of credit system may help to solve some concerns about the regressive nature of congestion pricing. While this policy may be focused on redistributing the time of day that drivers are on the road, not decreasing the number of cars coming into a city, it could be adjusted to respond to driverless cars. For instance, instead of generating an overall rebate, cities could use the revenue generated from congestion pricing to fund public transit or to subsidize affordable urban housing. Combined with investments in public transit, and the creation of a useful framework for driverless car sharing within the city, congestion pricing may be another tool with which to encourage density.

\footnotetext{
216 In London, for example, concerns about the boundary for the congestion charge zone related to the "impact that the zone will have on those living around the boundary and the impacts on land use in and around the zone. Many businesses inside the zone say that the extra cost incurred by the charge will result in higher prices for their customers." See Royal Geographical Society, Geography in the News, "Congestion Charging Ahead" (Feb. 10, 2003), available at http://www.rgs.org/NR/rdonlyres/7B0651E8-A8CB-4215-ADF74CCE74A85F0A/0/SMA_CP_CongestionCharging.pdf (last visited Feb. 3, 2016).

${ }^{217}$ David Schleicher, The City As A Law and Economic Subject, 2010 U. ILL. L. REV. 1507, 1561 (2010) (describing congestion pricing as a "pro-agglomerative policy.").

218 See, e.g., Richard Arnott, André de Palma \& Robin Lindsey, The Welfare Effects of Congestion Tolls with Heterogeneous Commuters, 28 J. TRANSP. ECON. \& POL'Y 139, 158 (1994).

${ }^{219}$ Kara M. Kockelman \& Sukumar Kalmanje, Credit-Based Congestion Pricing: A Policy Proposal and the Public's Response, TRANSPORTATION RESEARCH 39A: 671-690 (2005).
} 


\section{c. Public transit}

In tandem with measures that will support a smooth transition to self-driving cars, municipalities should invest in existing or planned public transit options that promote dense development. This suggested investment may seem counterintuitive, given that driverless cars may decrease demand for public transit. But public transit systems still provide the greatest potential for density, and the greatest ability to address the needs of a diverse citizenry. ${ }^{220}$ Because opposition to public transit is likely only to increase as driverless car technology becomes fully developed, and those with financial interest in it become more organized and coordinated, cities would do well to invest now in the kinds of public transit that will allow for the growth of urban centers and serve all citizens.

Public transit both needs density to flourish, and fosters further density. At the most basic level, public transit promotes density because it simply takes up less space per person moved. Some predictions estimate that, during rush hour, "a trip by car may consume up to twenty-five times more time-area than the same trip made by bus, and more than sixty times the time-area consumed by rapid transit." 221 Using public transit options instead of private automobiles frees up precious urban space for housing and other needs. By providing alternatives to the car, public transit options also help to break ties with the automobile in a much more dramatic way than driverless cars. ${ }^{222}$

220 See generally Hannibal B. Johnson, Making the Case for Transit: Emphasizing the "Public" in Public Transportation, 27 Urb. Law. 1009 (1995); see also, e.g., James A. Kushner, Affordable Housing As Infrastructure in the Time of Global Warming, $42 / 43$ Urb. Law. 179, 198-99, 201-02 (2011); Patrick Moulding, Fare or Unfair? The Importance of Mass Transit for America's Poor, 12 Geo. J. on Poverty L. \& Pol'y 155, 164 (2005) (noting that minorities and low-income households account for 63\% of the nation's transit riders); $c$. Charles Montgomery, HAPPY CITY: TrANSFORMING OUR LiVES THROUGH URBAN DESIGN 233-241, Farrar, Straus \& Giroux (2013) (describing importance of transit systems to urban equality). Of course, historic patterns of exclusion with regard to public transit may cut against this access argument. See, e.g., Sarah Schindler, Architectural Exclusion: Discrimination and Segregation Through Physical Design of the Built Environment, 124 Yale L.J. 1934, 1962 (2015) (describing detriment suffered by low-income communities and communities of color with regard to access to employment, recreational, and other activities due to intentional exclusion of transit stops from white, higherincome areas).

221 Patrick Moulding, Fare or Unfair? The Importance of Mass Transit for America's Poor, 12 GEO. J. ON POVERTY L. \& POL'Y 155, 162 (2005) (citing Vukan R. Vuchic, TransPORTATION FOR LIVABLE CITIES 55 (1999)).

222 See, e.g., James A. Kushner, Global Climate Change AND the RoAD to EXTinction: THE LEGAL AND

PlanNING RESPOnSE 182 (Carolina Academic Press 2009) (proposing that the foremost goal for local governments 
In addition to furthering density goals, continued investment in public transit is important for equal access to transportation. While Sven Beiker, executive director of the Center for Automotive Research at Stanford University, has said that "[v]ehicle automation is the point where personal mobility and public transportation come together," 223 private cars are unlikely to serve the needs of all members of the population. Whether self-driving cars are owned privately or by cities, they will likely require either access to large amounts of financial resources to purchase a vehicle, or technology, such as credit cards or mobile phone applications, that would be used to access a shared fleet. Either option risks excluding lower-income segments of the population from this new transportation tool, and reinforcing a two-tiered system of transit. While it is possible that shared fleets may provide end-of-line access and private transit in currently underserved areas, ${ }^{224}$ public transit is likely to continue to play an important role in ensuring equal access to transportation. The prospect of driverless vehicles may provide an angle, reasoned or otherwise, to oppose expenditures on public transit, or to reduce the level of engagement of higher-income, enfranchised advocates. ${ }^{225}$ For instance, the Pinellas Suncoast Transportation Authority in Florida's Pinellas County, which covers the Tampa and St. Petersburg metropolitan areas, created a plan to address the many transportation problems in the County through expansion of bus service and construction

planning for more sustainable transportation is to "plan and implement a public transport system that can gradually replace the automobile as the principle means of transport," and that, to make those plans, "housing settlements, jobs, commercial and recreational destinations should be planned around transport").

${ }^{223}$ David Z. Morris, "Trains and self-driving cars, headed for a (political) collision," FORTUNE, Nov. 2, 2014, available at http:/ / fortune.com/2014/11/02/trains-autonomous-vehicles-politics/?iid=sr-link1 (last visited Dec. 21, 2015).

224 An Uber-funded study done by third party researchers suggests that, in terms of response time and cost, its services provide better services to underserved neighborhoods than taxis. See generally Botec Analysis Corporation, "Faster and Cheaper: How Ride-Sourcing Fills a Gap in Low-Income Los Angeles Neighborhoods," available at http://botecanalysis.com/wp-content/uploads/2015/07/LATS-Final-Report.pdf (last visited Jan. 29, 2016). 225 See, e.g., Anne Lutz Fernandez, "Magic Cars and Silver Bullets: Will the Self-Driving Car Save the World?," Streetsblog USA (June 5, 2013), http://usa.streetsblog.org/2013/06/05/magic-cars-and-silver-bullets-will-the-selfdriving-car-save-the-world/ (noting that "[p]erpetuating the belief that a magic car will be the silver bullet that solves our transportation problems doesn't just focus too narrowly on automotive solutions to transportation problems-it slows down progress on non-automotive solutions" as detractors of transit can undermine the necessary large investments in public works projects by pointing to the potential of driverless vehicles). 
of a 24-mile light rail system. ${ }^{226}$ When the plan, which would have been funded through a one-cent sales tax, was put up for a referendum in November 2014, it failed by huge margins. ${ }^{227}$ Although opponents of the plan had many arguments for their position, one of them was the idea that traditional forms of public transportation would be rendered obsolete by autonomous vehicle technology. ${ }^{228}$ Because driverless cars can be privately owned, and require less government funding, they may be appealing to those who disfavor public works projects. ${ }^{229}$ Planners also may be reluctant to invest limited capital on projects that could soon be rendered obsolete. ${ }^{230}$ These arguments may only gain in strength as driverless cars grow in popularity, meaning that investment in public transit may be easier now than in the future.

\section{Pro-Density, Not Anti-Car}

Above all, in considering information about the driverless car's likely impacts and planning for implementation of this new technology, planners should keep in mind that the driverless car is just the latest iteration in what is likely to be a long line of technologies that make it possible to work and live farther apart than ever before. The above measures may help to facilitate discussion of the impacts of driverless cars for the environment, and assist governments in planning for a denser future.

It may be tempting at times to consider simple solutions that address only the driverless car, without actually planning for density. For instance, some may propose to simply restrict driverless

\footnotetext{
226 Tony Marrero, "Voters reject Greenlight Pinellas," The Tampa Bay Times (Nov. 4, 2014), available at http://www.tampabay.com/news/politics/elections/greenlight-pinellas-doing-poorly-in-early-results/2205105 (last visited Dec. 21, 2015).

227 Tony Marrero, "Voters reject Greenlight Pinellas," The Tampa Bay Times (Nov. 4, 2014), available at http://www.tampabay.com/news/politics/elections/greenlight-pinellas-doing-poorly-in-early-results/2205105 (last visited Dec. 21, 2015).

${ }^{228}$ David Z. Morris, "Trains and self-driving cars, headed for a (political) collision," FORTUNE, Nov. 2, 2014, available at http:// fortune.com/2014/11/02/train-autonomous-vehicles-politics/?iid=sr-link1 (last visited Dec. 21, 2015).

${ }^{229}$ David Z. Morris, “Trains and self-driving cars, headed for a (political) collision," ForTUNE, Nov. 2, 2014, available at http:/ / fortune.com/2014/11/02/train-autonomous-vehicles-politics/?iid=sr-link1 (last visited Dec. 21, 2015).

230 Erick Guerra, Planning for Cars that Drive Themselves, JOURNAL OF PLANNING EDUCATION AND RESEARCH (2015), at 6.
} 
cars to urban areas. Such an option, even if legally viable, ${ }^{231}$ is unwise. First, artificially restricting the marketplace for driverless cars to urban areas (however those areas are defined) would deny the benefits of self-driving cars to those in suburban areas. As noted above, those benefits would be considerable. In particular, crashes outside of urban areas are responsible for approximately half of

231 A restriction of driverless cars to urban areas would likely provoke a variety of legal challenges. For instance, suburban residents may raise an equal protection complaint regarding their inability to travel in a self-driving car in the same way as their urban counterparts. Generally speaking, the equal protection clause protects similarly situated persons from being treated differently. Where a law does not burden a constitutional right, courts are highly deferential to the legislature, and will look only to whether the law is reasonable and bears a rational basis to a permissible state objective. See, e.g., Vill. of Belle Terre v. Boraas, 416 U.S. 1, 8 (1974). Thus, whether action by a state to limit licensure of driverless cars to certain geographic bounds would pass muster under the equal protection clause of the United States Constitution will depend on whether limiting suburban sprawl is a permissible objective, and whether a restriction on driverless cars is a rational means of accomplishing that goal. While federal courts have recognized a constitutional right to travel that encompasses the "right to go from one place to another, including the right to cross state borders while en route," that right does not guarantee access to any particular mode of transportation. Saenz v. Roe, 526 U.S. 489 , 500 (1999); Miller $v$. Reed, 176 F.3d 1202, 1205 (9th Cir. 1999); City of Houston v. F. A. A., 679 F.2d 1184, 1198 (5th Cir. 1982). Thus, where a town banned an entire mode of interstate transportation-vehicular ferries and high-speed ferries-in the interest of "protect[ing] the welfare of Town residents and the integrity of the local environment," and nothing in the record suggested that the rule was motivated by preventing traffic from outside the state, the court found that no constitutional right had been burdened. Town of Southold v. Town of E. Hampton, 477 F.3d 38, 54 (2d Cir. 2007). In this case and others, courts have frequently found that both preservation of local character and environmental protection are legitimate interests. The same result could likely be said of the state's interest in avoiding sprawl and its many negative consequences. Moreover, because the restriction on driverless cars in the suburbs would likely be considered a rational means of attaining that interest, any equal protection claims would be unlikely to succeed.

In a somewhat related context, in 2014 taxi drivers filed suit against the city of Chicago regarding its regulations for transportation network companies ("TNCs") like Uber and Lyft. The taxi driver plaintiffs alleged that those regulations, which impose substantially different requirements on TNCs than taxis in terms of insurance, driver qualifications, and others, are unlawful for a number of reasons, including violation of the equal protection clause. See Illinois Transportation Trade Ass'n v. City of Chicago, 134 F.Supp.3d 1108, 1110-11 (N.D. Ill. 2015). The judge dismissed all of the taxi drivers' claims but those focused on equal protection, finding that the city had not articulated a rational basis for the difference in treatment. Id. at 1114-15. Although the distinction between urban and suburban populations is likely easier to articulate, the lawsuit sounds a cautionary note for regulating new transportation technologies.

A restriction on driverless cars might also be challenged under the Takings Clause of the United States Constitution, which prohibits the taking of property by the government without just compensation. Where government regulations go too far toward impeding reasonable, investment-backed expectations regarding the value of property, a court may find a taking. Here, suburban property owners could potentially argue that the inability to operate their driverless cars deprived them of the total value of their already-purchased property-in the case of those owners who had already purchased self-driving vehicles before the regulations went into effect — or that the impacts of not being able to take advantage of this technology diminished the value of their property. The latter case is unlikely to succeed, as "[d]iminution in the value of property, however serious, is insufficient to demonstrate a taking." Rancho de Calistoga $v$. City of Calistoga, 800 F.3d 1083, 1090 (9th Cir. 2015). In the former case, for those property owners who had already purchased a vehicle, there may be a closer call about whether a taking was effectuated. The remedy for a taking is government compensation; however, if these regulations were put in place before driverless car technology was widely disseminated, the cost to the government of replacing the value of affected vehicles may be relatively low. 
the deaths from automobile accidents each year. ${ }^{232}$ Withholding technology that could eliminate that many deaths may be ethically questionable. Moreover, the driverless car's possible psychological impacts in weakening the link between car and human may have their greatest impacts in the suburbs. And just as driverless technology should not be restricted to only one area, cities should not restrict their choices about infrastructure to changes that would be desirable or necessary only in the event that driverless cars are the dominant form of transportation. ${ }^{233}$ Either of these moves would be part of a long tradition of planning decisions that focus only on the transportation form of the moment.

Cities have long been shaped by transportation; to the extent that density characterizes older settled areas, it is generally because of the need to be close to transit, whether by rail, river, or ocean. ${ }^{234}$ And development has generally been predicated on an assumption that the form of transportation essential at the time of construction would forever be dominant. Suburban homes, for instance, are generally constructed around an assumption that automobiles and road construction will forever satisfy the transit needs of the American population. ${ }^{235}$ Because transit infrastructure is not planned to be anything other than permanent, each transit phase leaves a permanent mark on the landscape in terms of infrastructure, and a "distinct pattern of community design" ${ }^{236}$ vulnerable to obsolescence. A ban on driverless cars in the suburbs, or a city molded

232 "Roadway and environment," Insurance Institute for Highway Safety Highway Loss Data Institute, available at http://www.iihs.org/iihs/topics/t/roadway-and-environment/fatalityfacts/roadway-and-environment (last visited Jan. 18, 2016).

${ }^{233}$ Cf. Press Release, "NACTO Releases Policy Recommendations for the Future of Automated Vehicles" (June 23, 2016), http:/ / nacto.org/2016/06/23/nacto-releases-policy-recommendations-for-automated-vehicles/ (quoting statement by Janette Sadik-Khan, Transportation Principal at Bloomberg Associates and NACTO Chair (and former Commissioner of the New York City Department of Transportation under Mayor Michael Bloomberg) that "[i]nstead of adapting our cities to accommodate new transportation technologies, we need to adapt new transportation technologies to our cities in ways that make them safer, more efficient, and better places to live and work").

${ }^{234}$ Cf. William W. Buzbee, "Urban Sprawl, Federalism, and the Problem of Institutional Complexity," 68 FORDHAM L. REV. 57, 64-67 (2000).

${ }^{235}$ Roger K. Lewis, "Shaping the City: Seeking a New Template for Truly Smart Growth,” Real Estate, THE WASHINGTON POST (April 15, 2011).

${ }^{236}$ James A. Kushner, The Post-Automobile City: Legal Mechanisms to Establish the PeDESTRIAN-Friendly CITY 1-3 (Carolina Academic Press 2004). 
around driverless technology, would simply be a band-aid, a temporary fix to get us past the most recent technological wonder. But it would not help us plan for the next round, and the one after.

Like the horse, streetcar, and human-controlled automobile before them, driverless cars can be expected to be followed by still newer modes of transit, ${ }^{237}$ with characteristics and consequences difficult to foresee. The environmental necessity of density is the one constant. The goal should therefore be density untethered from any particular mode of transit. And it should be density even as technology permits otherwise. "The future is always stranger than we expect: mobile phones and the Internet, not flying cars." ${ }^{238}$ But it is precisely because we do not know in what form our future transportation needs and technologies will come that land use goals should dictate our transportation strategies, not the other way around. If we don't rethink how we live, and engage in the difficult planning processes at the regional and local levels that will elevate density to a planning goal, we will be heading into the future once again unprepared. For that reason, more comprehensive planning from the outset of this new technology is essential.

\section{Conclusion}

Norman Bel Geddes, in his vision of the future of the driverless car, proclaimed that " $[\mathrm{a}] \mathrm{n}$ America in which people are free, not in a rhetorical sense, but in the very realistic sense of being freed from congestion, waste and blight—free to move out on good roads to decent abodes of life-free to travel over routes whose very sight and feel give a lift to the heart- that is an America whose inner changes may far transcend the alterations on the surface." ${ }^{239}$ He and others viewed the highway as a mechanism for uniting the country, and for positive social change. This view is part of

\footnotetext{
237 See David Levinson, "Climbing Mount Next: The Effects of Autonomous Vehicles on Society,” 16 MINN. J.L. SCI. \& TECH. 787, 790-91 (2015) (describing the "S-curve" for transportation technologies over time, through birth, growth, maturity, and decline).

238 Tad Friend, “Tomorrow's Advance Man: Marc Andreessen’s Plan to Win the Future,” THE NEW YORKER (May 18, 2015) http://www.newyorker.com/magazine/2015/05/18/tomorrows-advance-man; see also, e.g., Donald Shoup, THE High COST OF Free PARKING, American Planning Association 6 (2011) (noting that "[a] simple projection is often a poor forecast because technology and policy can change").

239 Norman Bel Geddes, MAgIC MOTORWAYs 294-95 (Random House 1940).
} 
a long tradition of the American relationship with the automobile, in which " $[t]$ he essence of the motorway idea is that of new opportunity," ${ }^{240}$ and of exploring new frontiers.

Part of this romantic vision regarding the automobile has to do with a desire to experience an "“affordable pastoralism' away from the congestion of the city." 241 Unfortunately, this impulse has serious repercussions for the larger ecosystem in which we live. "Decisions about how and where we build our communities have significant impacts on the natural environment and on human health." ${ }^{242}$ Ecosystems in the United States are already experiencing pressure and species loss due to habitat fragmentation and destruction. Anticipated population growth in the United States, and the potential for driverless car technology to encourage development far outside metropolitan areas, are likely to lead to severe environmental damage if measures are not put in place to instead encourage density.

Americans have long viewed the country as a land without limit, ${ }^{243}$ and the frontier impulse for settlement and sense of national identity connected to a far-reaching highway system has characterized the country's growth patterns. Perhaps, however, we have arrived at a point where those values can be reframed. Dwight D. Eisenhower, a driving force behind the national highway system, began an address to Congress regarding highway funding by remarking that "[o]ur unity as a nation is sustained by free communication of thought and by easy transportation of people and goods." ${ }^{244}$ New technologies make questions of communication and access very different, and we

\footnotetext{
240 Norman Bel Geddes, Magic Motorways 290 (Random House 1940).

241 Jamison E. Colburn, “Localism's Ecology: Protecting and Restoring Habitat in the Suburban Nation,” 33 ECOL. L. Q. 945, 980 (2006).

242 EPA, "Our Built and Natural Environments: A Technical Review of the Interactions Among Land Use, Transportation, and Environmental Quality" i, 2d ed. (2013).

243 Jason C. Rylander, "The Emerging Federal Role in Growth Management," 15 J. LAND USE \& ENVTL. L. 277,280 (2000).

${ }^{244}$ Dwight D. Eisenhower, Message to the Congress regarding highways, White House Office, Office of the Press Secretary to the President, Box 4, Press Releases Feb. 8-March 14, 1955; NAID \#16857605, available at http://www.eisenhower.archives.gov/research/online_documents/interstate_highway_system/1955_02_22_Message_t o_Congress.pdf (last visited Dec. 22, 2015).
} 
now have the luxury, ability, and obligation to plan our growth as a country in ways that will allow for the survival of the natural environment alongside the human population.

Driverless cars are both exciting feats of human engineering and very powerful tools with which to make longer distances possible, more enjoyable, and in demand. City and suburban government actors should integrate knowledge of the potential environmental impacts of these vehicles to promote growth in ways that will allow dense developments to flourish regardless of transportation technology. The alternative, allowing unthinking and uncontrolled use of new transportation to dictate the terms of the American landscape has been, and would now be, an inexcusable mistake. Our journey from horse to driverless car-and its attendant consequenceshas taken 200 years; we don't know what technological innovations the next 200 will hold. What we do know is that ever-greater expansion of the human footprint likely means disaster for the ecosystems in which we live. The coming of new possibilities for automobiles is the perfect time for reflection on what went wrong with our first car-fueled expansion, and to take measures to undo and avoid those harms as we move into an era of new transportation possibilities. 